University of Chicago Law School

Chicago Unbound

Journal Articles

Faculty Scholarship

2013

\title{
An FDA for Financial Innovation: Applying the Insurable Interest Doctrine to 21st Century Financial Markets
}

\author{
Eric A. Posner \\ E. Glen Weyl
}

Follow this and additional works at: https://chicagounbound.uchicago.edu/journal_articles

Part of the Law Commons

\section{Recommended Citation}

Eric Posner \& e. Glen Weyl, "An FDA for Financial Innovation: Applying the Insurable Interest Doctrine to 21st Century Financial Markets," 107 Northwestern University Law Review 1307 (2013).

This Article is brought to you for free and open access by the Faculty Scholarship at Chicago Unbound. It has been accepted for inclusion in Journal Articles by an authorized administrator of Chicago Unbound. For more information, please contact unbound@law.uchicago.edu. 


\title{
AN FDA FOR FINANCIAL INNOVATION: APPLYING THE INSURABLE INTEREST DOCTRINE TO TWENTY-FIRST-CENTURY FINANCIAL MARKETS
}

Eric A. Posner \& E. Glen Weyl

\begin{abstract}
The financial crisis of 2008 was caused in part by speculative investment in complex derivatives. In enacting the Dodd-Frank Act, Congress sought to address the problem of speculative investment, but it merely transferred that authority to various agencies, which have not yet found a solution. We propose that when firms invent new financial products, they be forbidden to sell them until they receive approval from a government agency designed along the lines of the FDA, which screens pharmaceutical innovations. The agency would approve financial products if they satisfy a test for social utility that focuses on whether the product will likely be used more often for insurance than for gambling. Other factors-such as a financial product's effect on the efficient allocation of capital - may be addressed if the answer is ambiguous. This approach would revive and make quantitatively precise the common law insurable interest doctrine, which helped control financial gambling before deregulation in the 1990s.
\end{abstract}

AUTHORS-Eric A. Posner is Kirkland \& Ellis Distinguished Service Professor and Aaron Director Research Scholar, University of Chicago Law School; E. Glen Weyl is Assistant Professor, Department of Economics, University of Chicago, and Fellow, Toulouse School of Economics. Posner acknowledges the financial support of the Russell Baker Scholars Fund at the University of Chicago Law School; Weyl acknowledges the support of the Institut D'Économie Industrielle. Thanks to Omri Ben-Shahar, John Bogle, Anthony Casey, Steve Choi, Darrell Duffie, Todd Henderson, William Hubbard, Adam Levitin, Thomas Philippon, Andrew Rosenfield, Jean Tirole, David Weisbach, and seminar participants at the Consumer Financial Protection Bureau, the Federal Trade Commission, the University of Chicago Law School, and the Chicago Booth School of Business for comments. Thanks to Alison Lanski, Ellie Norton, Michael Olijnyk, and Anthony Zhang for research assistance. An early and much shorter version of this paper circulated as a white paper under the name A Proposal for Limiting Speculation on Derivatives: An FDA for Financial Innovation and is available at http://ssrn.com/abstract= 1995077. 
INTRODUCTION .1308

I. BENEFITS AND HARMS OF FINANCIAL INNOVATION

A. Financial Markets and Social Welfare

B. Tests for Evaluating Financial Innovation

C. Examples...

D. Relationship with the Insurable Interest Rule and the Law Against Wagering .

II. AN FDA FOR THE FINANCIAL MARKET .

A. Structure of the Financial Products Agency

B. Parallels Between Pharmaceutical and Financial Products Regulation.. 1349

C. Criticisms and Qualifications

Derivatives are financial weapons of mass destruction.

-Warren Buffett ${ }^{\dagger}$

\section{INTRODUCTION}

Financial products are socially beneficial when they help people insure risks, but when these same products are used for gambling they can instead be socially detrimental. ${ }^{1}$ The difference between insurance and gambling is that insurance enables people to reduce the risk they face, whereas gambling increases it. A person who purchases financial products to insure herself essentially pays someone else to take a risk on her behalf. The counterparty may be better able to absorb the risk, typically because she has a more diversified investment portfolio or owns assets whose value is inversely correlated with the risk taken on. By contrast, when a person gambles, that person exposes herself to increased net risk without offsetting a risk faced by a counterparty: she merely gambles in hopes of gaining at the expense of her counterparty or her counterparty's regulator. To be sure, a person on one side of the transaction may be gambling while the person on the other side of the transaction may be insuring; then the question is whether the transaction on net reduces risks, increases them, or has no effect. In general, when we refer to insuring and gambling, we mean these

\footnotetext{
$\dagger$ Buffett Warns on Investment “Time Bomb," BBC (Mar. 4, 2003, 1:32 PM), http://news.bbc.co.uk/ 2/hi/2817995.stm.

${ }^{1}$ As we discuss below, new financial products also have other harms (informational racing) and benefits (information and incentive provision), but we believe that for most new products the insurance-gambling tradeoff is most important. In previous drafts and in parts of the literature, what we call "insurance" is referred to as "hedging" and what we call "gambling" is referred to as "speculation" or "betting." These terms are essentially equivalent, but we refer to insurance and gambling as they make the nature of the activity clearest to the broadest audience.
} 
net effects rather than the position on one side of the transaction. As we discuss below, gambling may have some ancillary benefits in improving the information in market prices. However, it is overwhelmingly a negative-sum activity, which, in the aggregate, harms the people who engage in it, and which can also produce negative third-party effects by increasing systemic risk in the economy.

This basic point has long been recognized, ${ }^{2}$ but has had little influence on modern discussions of financial regulation. Before the 2008 financial crisis, the academic and political consensus was that financial markets should be deregulated. ${ }^{3}$ This consensus probably rested on pragmatic rather than theoretical considerations: the U.S. economy had grown enormously from 1980 to 2007, and this growth had taken place at the same time as, and seemed to be connected with, the booming financial sector, which was characterized by highly innovative financial practices. With the 2008 financial crisis, this consensus came to an end, and since then there has been a significant retrenchment, epitomized by the passage of the DoddFrank Act, ${ }^{4}$ which authorizes regulatory agencies to impose significant new regulations on the financial industry.

But the Dodd-Frank Act is an empty vessel: it authorizes agencies to regulate without giving them much guidance as to how to regulate. ${ }^{5}$ So numerous questions remain open as to how the agencies should use their authority, and indeed whether the Dodd-Frank Act creates the proper regulatory structure.

In this Article, we propose a new approach to financial regulation that addresses the problem of financial gambling. We make two contributions. First, we propose a simple test for determining whether a financial instrument is socially valuable or socially costly, and argue that socially costly financial instruments should be banned. This argument is made in Part I. Second, we propose ex ante regulation of the market in financial derivatives, ${ }^{6}$ where financial innovators must submit proposed new

2 In the economics literature, the idea was first formalized by Jack Hirshleifer and, in a form closer to that we consider, by Itzhak Gilboa, Dov Samet, and David Schmeidler. See Jack Hirshleifer, The Private and Social Value of Information and the Reward to Inventive Activity, 61 AM. ECON. REV. 561 (1971); Itzhak Gilboa et al., Utilitarian Aggregation of Beliefs and Tastes, 112 J. POL. ECON. 932 (2004). However, the underlying idea is quite old, and can be found, for example, in debates about gambling and insurance in eighteenth-century Britain. See infra notes 62-63 and accompanying text.

3 Gillian TetT, Fool's Gold: How the Bold Dream of a SMall Tribe at J.P. Morgan Was Corrupted by Wall StreEt Greed and Unleashed a CaTASTRophe 34-35 (2009).

${ }^{4}$ Dodd-Frank Wall Street Reform and Consumer Protection Act, Pub. L. No. 111-203, 124 Stat. 1376 (2010) (codified as amended in scattered sections of 12, 15, 22, and 26 U.S.C.).

5 See, e.g., David SKeel, THE NEW Financial Deal: Understanding the Dodd-Frank ACT AND ITS (UNINTENDED) CONSEQUENCES (2011); Saule T. Omarova, License to Deal: Mandatory Approval of Complex Financial Products, 90 WASH. U. L. REV. 63, 77-78 (2012).

6 We use the term "derivatives" loosely to refer to a class of financial instruments whose value is derived from underlying assets, with a focus on recent financial innovations. The proper definition of derivatives is in dispute, and commentators and courts typically refer to a specific group of products 
financial products to the government for approval before they may sell them to the public. We will refer to this agency as the Financial Products Agency (FPA), although we are agnostic as to whether a new agency should be created or existing agencies, such as the SEC or CFTC, should be given these powers. ${ }^{7}$ We draw on the analogy of the Food and Drug Administration (FDA), which similarly has the power to ban new pharmaceuticals that do not meet stringent safety standards. This argument is made in Part II.

We do not write on a clean slate. Criticism of gambling goes back centuries, ${ }^{8}$ and the basic welfare-reducing implications of this practice have long been recognized. We also rely on some recent economic literature that provides technical explanations as to how one can distinguish between value-reducing gambling and value-increasing insurance. ${ }^{9}$ In addition, numerous legal scholars have addressed how the government should regulate the financial markets. ${ }^{10}$ Most of the literature focuses on traditional

(for example, options and swaps), although the term may encompass many other products such as insurance policies. For a useful discussion, see Timothy E. Lynch, Derivatives: A Twenty-First Century Understanding, 43 LOY. U. CHI. L.J. 1, 15-30 (2011).

${ }^{7}$ After we circulated a draft of this paper on SSRN, we learned about a then-unpublished draft that independently proposes an FDA-like approach to financial regulation. See Omarova, supra note 5. Readers should consult this paper, as well. Our proposal also builds off an earlier unpublished draft and published op-ed piece written by one of us. See E. Glen Weyl, Is Arbitrage Socially Beneficial? (Oct. 2007) (unpublished manuscript) [hereinafter Weyl manuscript], available at http://home.uchicago.edu/ weyl/Second_Draft_Arbitrage.pdf; Glen Weyl, Op-Ed., Financial Guidance from FDA, Bos. GLOBE, Dec. 3, 2008, at A19. Other related papers outside the law review literature include JOSEPH E. STIGLITZ, COMM'N OF EXPERTS OF THE PRESIDENT OF THE UN GEN. ASSEMBLY ON REFORMS OF THE INT'L MONETARY \& FIN. SYS., PRINCIPLES FOR A NEW FINANCIAL ARCHITECTURE, available at http://www. un.org/ga/president/63/commission/newfinancialarchitecture.pdf; Sumit Agarwal et al., The Age of Reason: Financial Decisions over the Life Cycle and Implications for Regulation, BROOKINGS PAPERS ON ECON. ACTIVITY, Fall 2009, at 51; Gerald Epstein \& James Crotty, Controlling Dangerous Financial Products Through a Financial Pre-Cautionary Principle, 72 EKonomiaz 270 (2009) (advocating ex ante regulation of financial products on the basis of a precautionary principle); and James Crotty \& Gerald Epstein, A Financial Precautionary Principle: New Rules for Financial Product Safety (Wall St. Watch, Working Paper No. 1, 2009). These papers address issues beyond the scope of our Article and do not provide the same test that we propose.

8 See, e.g., Geoffrey ClaRk, BetTING ON Lives: The CUlture of LifE INSURANCE IN ENGLAND, 1695-1775 (1999).

${ }^{9}$ Stefano G. Athanasoulis \& Robert J. Shiller, World Income Components: Measuring and Exploiting Risk-Sharing Opportunities, 91 AM. ECON. REV. 1031 (2001); Alp Simsek, Speculation and Risk Sharing with New Financial Assets (Nat'l Bureau of Econ. Research, Working Paper No. 17,506, 2011); Markus K. Brunnermeier et al., A Welfare Criterion for Models with Distorted Beliefs (Feb. 2012) (unpublished manuscript), available at http://papers.ssm. com/abstract=2021600.

${ }^{10}$ See Erik F. Gerding, Credit Derivatives, Leverage, and Financial Regulation's Missing Macroeconomic Dimension, 8 BERKELEY BUS. L.J. 29, 37-38 (2011) (making a similar argument). For other related work in the legal literature, see Robert S. Bloink, Does the Dodd-Frank Wall Street Reform Act Rein In Credit Default Swaps? An EU Comparative Analysis, 89 NEB. L. REV. 587, 632-33 (2011) (expressing cautious skepticism about regulation because of the benefits of financial products); Stephen Choi, Regulating Investors Not Issuers: A Market-Based Proposal, 88 CALIF. L. REV. 279, 333-34 (2000) (proposing market-based regulation of securities markets); Jill E. Fisch, Rethinking the 
methods of financial regulation, such as disclosure requirements, ${ }^{11}$ and recently, the special need for financial regulation to protect consumers. ${ }^{12}$ We do not address either of these topics: although some of our comments on heuristic arbitrage are related to consumer protection, our concern is the overall health of the financial markets, and our proposal would apply both to inexperienced and sophisticated investors. Only a few legal scholars have focused on the problem of gambling per se. Notably, Lynn Stout, in a 1999 article, expressed support for derivatives regulation based in large part on antigambling considerations. ${ }^{13}$ As far as we know, our Article provides a more concrete proposal grounded more firmly in economic principles than the rest of the literature.

Our proposal is not as radical as it might seem at first. Our main goal is to regulate a form of gambling that takes place in financial markets. This type of regulation goes back at least to the eighteenth century when the British government enacted a statute that introduced the "insurable interest" rule to insurance markets. The main purpose of the insurable interest rule was to prevent people from using insurance contracts to gamble. ${ }^{14}$ The rule remains a fixture of the common law and state insurance regulation. There is also a longstanding common law rule against wagering, which courts have on occasion used to void certain kinds of financial products. ${ }^{15}$ Additional rules have long been used to limit gambling in financial markets. ${ }^{16}$ Indeed, not even the idea of ex ante regulation of derivatives is new. The SEC and particularly the CFTC have long had the power to curb gambling in the financial markets. Before 2000, financial innovators who sought to trade new derivatives on commodities exchanges were required

Regulation of Securities Intermediaries, 158 U. PA. L. REV. 1961 (2010); and Brian J.M. Quinn, The Failure of Private Ordering and the Financial Crisis of 2008, 5 N.Y.U. J.L. \& BUS. 549, 602-03 (2009) (proposing additional regulation of financial markets).

11 See, e.g., Xue Wang, Increased Disclosure Requirements and Corporate Governance Decisions: Evidence from Chief Financial Officers in the Pre-and Post-Sarbanes-Oxley Periods, 48 J. ACCT. RES. 885 (2010); John Y. Campbell et al., The Regulation of Consumer Financial Products: An Introductory Essay with Four Case Studies (Harvard Kennedy Sch., Working Paper RWP10-040, 2010), available at http://dash.harvard.edu/bitstream/handle/1/4450128/Madrian_TheRegulationof.pdf.

12 See, e.g., Oren Bar-Gill \& Elizabeth Warren, Making Credit Safer, 157 U. PA. L. REV. 1 (2008); Daniel Carpenter et al., Approval Regulation and Endogenous Consumer Confidence: Theory and Analogies to Licensing. Safety, and Financial Regulation, 4 REG. \& GoVERNANCE 383 (2010).

13 Stout uses Hirshleifer's insight to argue that courts should not enforce financial contracts that are used for gambling. See Lynn A. Stout, Why the Law Hates Speculators: Regulation and Private Ordering in the Market for OTC Derivatives, 48 DUKE L.J. 701 (1999); see also Timothy E. Lynch, Gambling by Another Name; The Challenge of Purely Speculative Derivatives, 17 STAN. J.L. BUS. \& FIN. 67 (2011) (discussing the relationship between gambling and derivatives markets); Omarova, supra note 5, at 68-74 (addressing the problem of speculation).

14 See RoBert H. JERry, II \& DOUGLAS R. RICHMOND, UNDERSTANDING INSURANCE LAW 275-82 (5th ed. 2012).

15 See, e.g., Irwin v. Williar, 110 U.S. 499, 510 (1884).

16 See Stout, supra note 13, at 713-34. 
to obtain the approval of the CFTC and related agencies before selling them. ${ }^{17}$ The CFTC used (or purported to use) an ill-defined "economic purpose" test to determine whether a derivative could be traded or not. Under this test, the applicant was required to show that the derivative served some legitimate economic purpose, such as insurance, and would not be used mainly for gambling. ${ }^{18}$ However, the CFTC liberalized its approval requirements prior to 2000 , and in 2000 Congress enacted the Commodities Futures Modernization Act, ${ }^{19}$ which ensured that these derivatives would continue to be unregulated. ${ }^{20}$ This law was the culmination of the deregulation of the 1990s and set the stage for an explosion in derivatives trading. From 2000 to 2008, trade in over-thecounter derivatives increased from $\$ 95.2$ trillion to $\$ 592$ trillion-a spike of $522 \% .^{21}$ Our proposal seeks to revive and develop the institutional status quo prior to 2000 and to provide a clearer and more precise rule for regulating derivatives.

We should be clear that we identify one specific problem with financial markets - the welfare-reducing effects of gambling on the gamblers themselves - and do not intend our proposal to be a comprehensive response to all the problems with financial markets. Thus, we ignore certain problems like fraud, which have already received a great deal of attention; the problem of confusion and misunderstanding, which may justify paternalistic regulation; and, for the most part, we ignore the problem of systemic risk, which is different from and more complicated than the problems we address. However, if speculative trading were suppressed, then systemic risk should decline as well because systemic risk is an outgrowth of the total risk in the financial system, which is increased by gambling. ${ }^{22}$

${ }^{17}$ Omarova, supra note 5 , at 89.

18 See Thomas Lee Hazen, Rational Investments, Speculation, or Gambling?-Derivative Securities and Financial Futures and Their Effect on the Underlying Capital Markets, 86 NW. U. L. REV. 987, 1029-31 (1992); Laurin C. Ariail, Note, The Impact of Dodd-Frank on End-Users Hedging Commercial Risk in Over-the-Counter Derivatives Markets, 15 N.C. BANKING INST. 175, 196-97 (2011).

19 Consolidated Appropriations Act of 2001, Pub. L. No. 106-554, § 1(a)(5), 114 Stat. 2763, 2763 (enacting the Commodity Futures Modernization Act of 2000 (CFMA), H.R. 5660, 106th Cong.).

${ }^{20}$ See Thomas Lee Hazen, Filling a Regulatory Gap: It Is Time to Regulate Over-the-Counter Derivatives, 13 N.C. BANKING INST. 123, 128-29 (2009) (discussing history). The Dodd-Frank Act repeals some provisions of the CFMA. For details, see Derivatives: LeGAL PRACTICE AND STRATEgIES $\S 16.06$ (Robert D. Aicher ed., Supp. 2011).

${ }^{21}$ BANK FOR INT'L SETTLEMENTS, OTC DERIVATIVES MARKET ACTIVITY IN THE SECOND HALF OF 2008, at 1 (2009), available at http://www.bis.org/pub1/otc_hy0905.pdf; Press Release, Bank for Int'l Settlements, Slowdown of the Global OTC Derivatives Market in the Second Half of 2000, at 1 (May 16, 2001), available at http://www.bis.org/publ/otc_hy0105.pdf.

22 Many others have argued that financial products used for gambling purposes, like CDSs, can also create systemic risk, which creates an additional reason for regulating them. See, e.g., Gerding, supra note 10 , at $63-65$. 


\section{BENEFITS AND HARMS OF FINANCIAL INNOVATION}

\section{A. Financial Markets and Social Welfare}

Financial markets are markets in which people lend money, make investments, and trade securities, including derivatives. Financial markets can be distinguished from the "real economy," where people trade goods and services. It is tempting to think that if the real economy should be largely unregulated (as it is), then the financial markets should be as well. However, there are important distinctions between financial markets and the real economy, and so the regulatory implications are different as well.

\section{Insurance Versus Gambling}

a. Insurance.-Most individuals face a variety of idiosyncratic risks in their lives related to the sources of their labor income (their firm, industry, country, etc.), the price levels they face (currency risk, transport costs, housing prices, etc.), natural disasters, and other shocks. They may also face risks associated with the limited pool of capital investments available to them. Financial markets clearly help solve these problems by facilitating insurance and by allowing more diversified financial investments.

In economic terms, most people are assumed to be risk averse, which means that they will choose an investment that pays off with high probability to an investment that pays off with low probability, even if the expected value of the two investments are the same. ${ }^{23}$ For example, most people would choose a certain payoff of $\$ 10,000$ to a $50 / 50$ payoff of $\$ 20,000$ or $\$ 0$, even though the expected value of the two investments is the same. Commentators attribute this phenomenon to the diminishing utility of money. ${ }^{24} \mathrm{~A}$ person gains more in utility as she goes from $\$ 0$ to $\$ 10,000$ than she gains as she goes from $\$ 10,000$ to $\$ 20,000$. Thus, she prefers an outcome of $\$ 10,000$ in all states of the world to an outcome of $\$ 0$ in one state of the world and an outcome of $\$ 20,000$ in another state of the world, where the probability of each state of the world is 0.5 .

For this reason, a person who faces a risk of a negative shock to her income (like job loss or ill health) will be willing to buy insurance, which, in effect, transfers wealth from the "good state" to the "bad state." Consider an example taken from the early modern period when insurance markets were in their infancy. Suppose that merchants outfit ships and send them across the ocean to trade with foreign countries. Each merchant owns a ship laden with goods, which we will suppose is worth $\$ 100$. The ship faces a $1 / 100$ risk that it will be captured by pirates or sunk in a storm. If a merchant loses his ship, he will be ruined. Now suppose that 100 merchants

\footnotetext{
23 See Robert COOTER \& THOMAS ULEN, LAW \& ECONOMics 44-46 (6th ed. 2012).

24 See id.
} 
enter an agreement under which they promise to share the loss if a ship is sunk. If, for example, each merchant agrees to pay the victim $\$ 1$, then in expectation, each merchant bears only a $\$ 1$ loss (the $\$ 1$ payment if his ship does not sink and receipt of $\$ 99$ if his ship does sink). Thus, for each merchant, a $1 / 100$ risk of losing $\$ 100$ has been transformed from a low risk of losing a large amount to the certainty of losing a very small amount. The deal is mutually advantageous because of the merchants' risk aversion. Today, an insurance company would serve as an intermediary-receiving the $\$ 1$ premiums from the merchants and then paying out to the victimbut the principle is the same.

There are countless other examples of people insuring themselves against various financial shocks. For example, farmers can insure themselves against adverse price movements for their products by entering the futures market, where they sell their products in advance of the harvest. A person who owns a great deal of real estate might insure herself against adverse price movements in the real estate market by purchasing financial products whose value is uncorrelated (or, ideally, inversely correlated) with the value of real estate. Businesses also purchase insurance. Although large businesses are probably not risk averse in the same sense as individuals (as shareholders can protect themselves against risk by diversifying their holdings), they often buy insurance. They may seek to minimize the risk that adverse price movements will drive them into bankruptcy, where organizational capital is lost, or possibly because managers themselves are risk averse about their jobs or about the availability of external capital for investments.

The key thing to note about this insurance is that the conditions under which it provides a satisfying explanation for financial activity are simple and clear. Individuals on the two sides of a trade should be exposed to some source of risk, and the trade they undertake should mitigate their aggregate exposure to risk. Where the person on one side of the transaction gambles and the other side insures, then we will refer to such a transaction as an "insurance" transaction only if aggregate risk is reduced.

b. Gambling.-Different individuals within financial markets often have, or act as if they have, different views about future economic events. These (de facto) differences of opinion are deeper than mere differences in information. Some are simply the outcomes of differing opinions and beliefs, which are not terribly different from those motivating gambling. Others represent the fact that tax or regulatory treatment is different for various market participants, and thus equivalent assets may be of differing values to different participants without being of different social value in the hands of the participants; such "gambling" is really a form of regulatory or tax arbitrage. Similar effects may arise even when no explicit regulations are in place but investors judge assets based on imperfect heuristics; if agents in one jurisdiction use the rating of a bond, for 
example, as an imperfect proxy for risk, they will effectively act as if they believe that such bonds are of uniformly lower risk than other assets, even if, in individual situations, this is not the case.

As argued by Itzhak Gibloa, Dov Samet, and David Schmeidler, as well as one of us (Weyl), gambling is harmful because it exposes the speculators to risk without fully compensating them. ${ }^{25}$ When two people bet over whether a coin will turn up heads, they each incur the risk that they will be poorer in the future, when, assuming that they are risk averse, the gain will not be sufficient to outweigh the loss in terms of utility. Thus, rational people will not engage in gambling in the first place unless (1) they like to gamble (in which case there are cheaper ways, like casinos, to satisfy this preference), (2) at least one party is confused (which we believe is extremely common), or (3) they are engaging in regulatory arbitrage (which is also extremely common ${ }^{26}$ ).

It is tempting to believe that a financial trade is like the sale of a commodity. Two people trade money for a TV set because each is made better off by the transaction; therefore, it must be the case that two people who, say, trade oil futures must be made better off by the transaction. However, that need not be the case. Suppose that two people hold identical portfolios and thus are equally exposed to the risk that the price of oil will rise. However, person 1 believes that the current price of $\$ 80$ is too low and that it will rise to $\$ 90$ next week, while person 2 believes that the price will stay at $\$ 80$. By entering the derivatives market, person 1 and person 2 could make a bet on the price of oil. For example, person 2 could agree to sell a barrel of oil to person 1 for $\$ 85$. If the price of oil stays at $\$ 80$, person 2 makes a profit of $\$ 5$ (by buying oil in the spot market for $\$ 80$ and reselling to person 2 for $\$ 85$ ); if the price of oil rises to $\$ 90$, person 1 makes a profit of $\$ 5$ (by buying oil from person 2 for $\$ 85$ and then reselling to the market for $\$ 90$ ). Note that normally the parties will settle their transaction without the delivery of oil.

The movement in the price of oil vindicates either person 1's prediction or person 2's prediction. Ex post, therefore, the transaction is a zero-sum game: one party will be better off at the expense of the other party. Furthermore, because the bet introduces greater risk into the lives of both participants, assuming both are risk averse, they are on average worse off from the transaction. Thus, regardless of who is right, both would agree that the transaction is inefficient and that if they gain from it, it is only at the greater expense of the other party.

We will return to the question of whether people should be permitted to gamble. For now, we note only that if people should be permitted to

\footnotetext{
25 Gilboa et al., supra note 2; Weyl manuscript, supra note 7, at 4-5.

26 "Regulatory arbitrage consists of those financial transactions designed specifically to reduce costs or capture profit opportunities created by differential regulations or laws." Frank Partnoy, Financial Derivatives and the Costs of Regulatory Arbitrage, 22 J. CORP. L. 211,227 (1997).
} 
gamble, there is no reason to permit them to gamble using the financial markets, where many people cannot understand the nature of their transactions. ${ }^{27}$ But probably the major reason for gambling by sophisticated businesses is regulatory (or tax) arbitrage. Consider, for example, a bank, which under banking law must retain a capital cushion, which both reduces the risk of insolvency and limits the bank's ability to engage in high-risk, high-payoff investments. The reason for this rule is that the government pays off creditors when banks default, so creditors have inadequate incentives to monitor banks, and thus banks have excessive incentives to engage in risk. ${ }^{28}$ Banks have an incentive to participate in the derivatives market simply to increase their risk exposure, which is profitable because the government bears the downside if the gambles do not pay off, while the bank gains the upside if they do. This type of regulatory arbitrage is socially harmful not only, or even primarily, because it allows the regulation to be violated, but more importantly because the transaction itself increases risk while serving no economic purpose other than avoiding the regulation. Thus, even if one believes that the regulation is itself imperfect, the increase in risk undertaken to avoid it will typically outweigh whatever benefits might in principle accrue from it thereby being relaxed.

Gambling can also occur as a result of investors relying on heuristics, the rules that simplify investment. ${ }^{29}$ An ordinary person might use a heuristic like "buy a stock that has recently risen," falsely believing that if a stock has risen in the past, it is more likely to rise in the future. Municipalities and pension funds use heuristics like "buy a bond that has a AAA rating." Sophisticated investors like hedge funds can easily take advantage of such heuristics. When large numbers of people use the first heuristic, counterparties will infer that stocks will be at least temporarily overvalued and can earn returns by selling short after the price of a stock spikes. $^{30}$ The prevalence of the second heuristic caused financial institutions to construct AAA-related synthetic bonds by combining income streams from bonds that were in theory only weakly correlated, but the correlation within and across bonds turned out to be high enough to

\footnotetext{
27 See infra note 32 and accompanying text.

28 Richard SCOTT CARNELl ET AL., THE LAW OF BANKING AND FINANCIAL INSTITUTIONS 252-53 (4th ed. 2009).

${ }^{29}$ For a discussion, see Agarwal et al., supra note 7.

30 See Wemer F.M. De Bondt \& Richard Thaler, Does the Stock Market Overreact?, 40 J. FIN. 793 (1985); Werner F.M. De Bondt \& Richard H. Thaler, Financial Decision-Making in Markets and Firms: A Behavioral Perspective, in 9 HANDBOoKs IN OPERATIONS RESEARCH AND MANAGEMENT SCIENCE: FINANCE 385 (R.A. Jartow et al. eds., 1995). By "ordinary people," we mean to include even highly intelligent people, who frequently make the most elementary investing errors from the standpoint of financial theory. See, e.g., James J. Choi et al., \$100 Bills on the Sidewalk: Suboptimal Investment in 401(k) Plans, 93 REV. ECON. \& STAT. 748 (2011).
} 
massively increase systemic risk, which helped cause the financial crisis of 2008 and rendered many AAA bonds worthless. ${ }^{31}$

We should be clear that it is not the main purpose of our proposal to protect consumers and other unsophisticated investors from shady practices or their own ignorance. A variety of legal rules, plus the new Consumer Financial Protection Bureau (CFPB), are more appropriately tailored to address these problems. In addition, consumers can be exploited even when they engage in legitimate insurance transactions, which it is not our purpose to limit. Our goal is rather to deter financial gambling because it is welfare reducing and contributes to systemic risk.

It is sometimes suggested that gambling by unsophisticated investors is socially desirable because those investors' poor decisions in effect provide monetary rewards to people who invest in financial sophistication. The sophisticated parties enter into transactions with the unsophisticated parties in order to earn high returns, and these transactions produce a positive externality in the form of more accurate prices for securities. However, a well-known line of research has demonstrated that this intuition is wrong: markets are more efficient if unsophisticated investors are kept out of them. ${ }^{32}$

Gambling has its telltale signs, almost precisely opposite those of insurance. Gambling typically occurs between individuals who differ in some belief, heuristic, or exposure to some tax or regulatory provision, either directly or indirectly (through financial intermediaries who have had risk transferred to them through contracts).

c. The insurance-gambling spectrum.-Above we focused on the extreme cases of purely insurance transactions (where both sides gained insurance from the transactions) and purely gambling ones (where both sides added to their risk). We did this for conceptual clarity, but in reality, most transactions are somewhere in between these. Such transactions involve transfer of risks from those less able to bear them to those more able to bear them in the case of transactions that are mostly insurance, and the opposite direction in the case of mostly gambling transactions. It is therefore useful to consider a spectrum between purely insurance transactions and purely gambling ones.

- Pure insurance. A pure insurance transaction, like the arrangement between merchants described above, reduces the risk both sides face.

- Selling insurance. Perhaps a more common transaction involves an "insurance company" selling insurance for a fee to a purchaser who

\footnotetext{
31 Simon Johnson \& James KWAK, 13 BankERS: THE Wall STREet TAKEOVER AND THE NeXT FINANCIAL MELTDOWN 138-40 (2010).

${ }^{32}$ See, for example, J. Bradford De Long et al., Noise Trader Risk in Financial Markets, 98 J. PoL. ECON. 703 (1990), and the many papers building off of this work.
} 
has a concentrated risk. For example, individuals often purchase insurance on their house, car, or life to insure against events that could significantly reduce their wealth. This is a beneficial transaction because the purchaser of the insurance faces a concentrated risk while the seller of the insurance is diversified across many risks and thus is better able to bear the risk thus transferred to it. Issuing equity shares in a company similarly transfers the risk faced by that company to a broader group in the public, reducing the risk faced by the original owner without increasing by as much the risk faced by the public. Thus, while the insurance company or public do increase their risk, risk in the system as a whole has been reduced. Thus such "insurance selling" trades are a net benefit.

- Neutral risk transfers. A third category, which is neither net beneficial nor harmful, is when individuals with equally concentrated risks transfer them from one to the other. For example, if two individuals with a similar exposure to Microsoft's success or failure trade a share of the stock from one to the other, one gains risk while the other loses it. On net, risk in the system has neither increased nor decreased and thus the transaction is not a net gain or harm. The majority of trades in traditional securities, such as stocks and bonds, likely fall in this category or somewhere near it.

- Risk hoarding. Some risk transfers are harmful, however. For example, if a well-diversified index fund held by the public and owning a range of stocks sells a share of Microsoft to a Microsoft low-level employee whose livelihood is tied up in Microsoft's success, this trade increases the risk faced by the employee much more than it decreases the risk facing the index fund. Such transactions are on net gambling, reflecting the employee's desire to bet further on the success of her firm. ${ }^{33}$ Thus, despite decreasing the risk to the index fund, they are still harmful.

- Pure gambling. A pure gambling transaction is one where both sides increase the risk they face, as in the betting-on-oil example above.

Markus Brunnermeier, Alp Simsek, and Wei Xiong considered a number of difficult cases and performed calculations to determine whether the transactions should be classified as on-net gambling or on-net insurance. ${ }^{34}$ The standard they applied, and which we adopt, can be seen by noting that in an insurance transaction (whether pure or selling insurance), both sides believe the other is made better off by the transaction. In a gambling transaction, both sides believe the other is made worse off by

\footnotetext{
${ }^{33}$ However, as we will see below, we do not believe it is feasible to prevent all such transactions.

${ }^{34}$ See Brunnermeier et al., supra note 9.
} 
engaging in the transaction. ${ }^{35}$ That is, in a gambling transaction, while the two sides disagree (or are induced by heuristics or regulatory arbitrage to act as if they disagree), and therefore bet, about the likelihood of the outcome, both agree that the transaction is inefficient, in the sense that everyone would be better off if the transaction did not occur and some transfer was made between the parties. Brunnermeier and his coauthors call such transactions "belief-neutral inefficient," and it is the belief-neutral inefficiency of gambling transactions that we treat as their harm. ${ }^{36}$

\section{Capital Allocation and Informational Racing}

a. Capital allocation.-Firms need capital to make investments. Before the development of modern equity and bond markets, the owner of a firm would borrow from local banks or obtain equity investments from wealthy friends and acquaintances. Securities markets vastly expand the sources of financing. When banks are unwilling to make loans because they cannot take on any more default risk, firms can sell bonds on the market, reaching any member of the public who is willing to lend money in return for interest. Similarly, modern equity markets enable firms to obtain investments from the general public rather than a handful of rich friends. People are more likely to buy bonds and stocks than to make loans or unsecuritized investments because they can easily liquidate their positions by selling the securities if they need money. As we discuss below, other financial innovations like mutual funds have further extended the reach of the capital markets. ${ }^{37}$

Such liquidity can be seen as primarily a form of diversification, allowing small groups of investors in a firm to offload risk to the broader public; thus, it may be seen as fundamentally similar to the insurance function of markets. However, liquid financial markets also play an important and different role, helping ensure that capital gets to the right place by making clear how much other people value the activities of firms. An investor who buys Facebook stock is making a bet as to how much money Facebook will earn by providing a service in the real economy. If people could not buy stock in this "speculative" manner (or make loans, etc.), businesses with good ideas would have a great deal of trouble implementing those ideas and thus providing benefits to consumers, while companies with poor ideas might receive capital because no one would ensure that the price of their stocks or bonds remained low. Thus, financial market activity that helps prices adjust to their true value can influence the allocation of capital among potential products and thus improve economic efficiency.

\footnotetext{
35 Id. at $1-2$

${ }^{36}$ Id. at 2 (emphasis omitted).

37 See infra notes $69-76$.
} 
However, improving the informational efficiency of prices is only useful to the extent that it reflects the fundamental (social) value of the asset and affects the allocation of capital in the real economy. When fluctuations are too unpredictable and too driven by expectations of other traders' behavior or shifts in prices over too short of time scales to have any impact on the real economy, they cannot have value under this argument.

b. Informational racing.-Markets in the real economy produce an efficient allocation of resources, at least in ideal conditions. As discussed above, financial markets do not. Investors' incentives to purchase securities are not necessarily aligned with the public interest.

The problem is best understood by way of illustration. It takes its most extreme form in the phenomenon of high-speed trading, where hedge funds invest large resources to obtain information a nanosecond earlier than their rivals. In the recent film Margin Call, the CEO of the large investment bank at the center of the film lectures his assembled staff that on Wall Street there are three ways to make money: "Be first. Be smarter. Or cheat. Now I don't cheat. And although I like to think we have some pretty smart people in this building, it sure is a hell of a lot easier to just be first. ${ }^{938}$ The race to be first is epitomized by the recent construction of a $\$ 300$ million fiber optic cable connection between Chicago and New York that shaves three milliseconds off communication times between the two locations. ${ }^{39}$ This project was profitable because of the opportunities it created for numerous small arbitrages between the two markets using automated trading algorithms. Society gains little, if anything, from this tiny speedup because there are few, if any, real economic opportunities to use the information in the relevant time interval. For example, a farmer deciding whether to plant corn or wheat does not benefit from obtaining market prices a few milliseconds earlier. The information-racing effect was first studied by Hirshleifer and is widely accepted in the economics community ${ }^{40}$ Note that it does not only occur in extreme cases of very high-frequency trading. It occurs any time a firm can make more money from having information first, and society does not proportionally gain from the early arrival of this information for fundamental allocative purposes. Indeed, firms can overinvest in information from a social standpoint in other ways-for example, spending enormous resources developing algorithms that give them a slight advantage over other firms.

The hallmark of informational racing is trading that takes places more rapidly, unpredictably, and erratically than could impact real capital allocations. The appropriate metric for "too fast" is always the speed at

\footnotetext{
38 MARGIN CALl (Before the Door Pictures 2011).

39 Matt Dellinger, The Million-Dollar Millisecond, POPULAR SCI., May 2011, at 33.

${ }^{40}$ Hirshleifer, supra note 2.
} 
which decisions on real capital allocations or related economic decisions can take place. For example, a financial market in electricity futures may need, for purely economic purposes, to operate with great speed because automated generation systems depend on moment-to-moment changes in expected energy prices to determine current generation (though probably on the scale of seconds rather than milliseconds). On the other hand, little in terms of capital allocation would be lost if most common equities traded daily, or even weekly, rather than minute to minute, because stock issuance and other evaluations of corporate strategy based on share prices are very infrequent events. Thus, while a high speed of trades always provides an indication that trading is likely to be primarily racing rather than aiding capital allocation, the relevant speeds must be compared to those of fundamental decisionmakers in the relevant markets.

3. Positive Information Externalities.-Some financial instruments may generate positive externalities by revealing to the market and to policymakers information about underlying events. Prediction markets have been praised for this function. In a prediction market, people buy and sell securities that pay off based on a future event of general interest-such as the winner of the next presidential election. If the wisdom of crowds is revealed as a result of betting on the winner of the next presidential election, people who do not participate in the market but can learn about the value of the publicly traded securities can more easily plan their lives with this information. ${ }^{41}$ A similar claim has been made about Credit Default Swaps (CDS), insurance policies on bonds whose value reveals the likelihood that the firm that issues the underlying bonds will default. ${ }^{42}$ Investors can obtain information about the financial health of a borrower by observing the price of CDSs on the borrower's bonds.

However, we are skeptical about this claim in most cases. The market price of a CDS for a bond reveals no more information about the likelihood of default than the price of the bond itself relative to the price of a baseline risk-free security. If the firm is likely to default, then its bonds will trade at well below par value; the fact that the corresponding CDS will trade above par value (because the probability of default has risen above what it was when the CDS was sold) adds no information. Moreover, speeded-up disclosure of information is socially valuable only when it helps people plan in the real economy, and, as we have noted, private incentives to

\footnotetext{
41 See, e.g., Michael Abramowicz, Predictocracy: Market Mechanisms for Public and PRIVATE DECISION MAKING (2007); INFORMATION MARKETS: A NEW WAY OF MAKING DECISIONS (Robert W. Hahn \& Paul C. Tetlock eds., 2006).

${ }^{42}$ See Haibin Zhu, An Empirical Comparison of Credit Spreads Between the Bond Market and the Credit Default Swap Market (Bank for Int'1 Settlements, Working Paper No. 160, 2004).
} 
obtain information and the public benefit are not necessarily aligned..$^{43}$ In this respect, financial products yield positive informational externalities in similar situations to when they impact the real allocation of capital. However, informational externalities are distinct from the allocation of capital because they provide useful information to individuals not directly transacting in the assets, including and often primarily government policymakers.

\section{B. Tests for Evaluating Financial Innovation}

How can these considerations be given practical application? The Financial Products Agency should be guided by a test that it can use to evaluate proposed financial products. Ideally, the test should be as precise as possible, but it is a commonplace that regulatory agencies must apply general standards because of the complexity of regulated activity.

The general question is whether a proposed financial product advances social welfare or not. As we saw above, the answer to this question depends on how the financial product would affect the incidence of insurance (or gambling) and capital allocation (or informational racing), and whether the financial product would generate positive informational externalities. ${ }^{44}$ Some of our discussion will unavoidably be abstract, but we will supplement it with concrete examples in section C.

1. Insurance and Gambling.-The agency's fundamental standard would be whether the welfare gains from insurance allowed by a new product exceed the likely costs created by the gambling it facilitates. To identify the likely sources of demand, the agency's evaluation of a financial product would begin with a market demand analysis of the sort performed by any firm planning to market a new financial product. ${ }^{45}$ The agency would then classify these sources of demand as insurance or gambling and quantify the benefits and harms arising from each.

The method for performing this analysis proceeds as follows. ${ }^{46}$ Every financial product pays out if some event $X$ occurs and otherwise pays out a lower amount or nothing at all. ${ }^{47}$ The agency estimates the number of

${ }^{43}$ Hahn and Tetlock support prediction markets, but because of potential negative externalities including gambling, they advocate regulation by the CFTC. See Robert W. Hahn \& Paul C. Tetlock, $A$ New Approach for Regulating Information Markets, 29 J. REG. ECON. 265, 269-72 (2006).

44 Stout proposes a similar general test but does not go into detail as to how it would be administered in practice. Ultimately, she argues that if courts refuse to enforce derivatives, in practice gambling would be restricted while insurance would continue because parties that insure tend to be repeat players who will voluntarily comply with contracts, while parties that gamble will not be. See Stout, supra note 13, at 778-80. We do not put similar emphasis on nonlegal market dynamics.

45 Of the sort performed in, for example, Simsek, supra note 9.

46 We draw on Athanasoulis \& Shiller, supra note 9, and Simsek, supra note 9.

${ }^{47} X$ could be some general event like a sovereign default on a bond or a specific event like a person's death. 
people whose wealth or income is inversely correlated with $X$ and determines their next-best financial product for insuring against the loss of wealth or income that occurs when $X$ occurs. This information should be available from the firm seeking approval; after all, it should be incorporated in the demand analysis the firm uses to decide whether to market the financial product in the first place. The agency would thus just need to check the firm's calculations and ensure that the firm used reliable data, which in most cases will be publicly available. Using this method, the agency will obtain an estimate of the total value of the financial product for insurance purposes-essentially, the aggregate willingness to pay of all the people whose wealth or income is inversely correlated with $X$.

The crucial step would be to determine the costs of the new instruments based on how many individuals would be interested in speculating on them and at what volume. The key to a careful analysis is to break down speculative demand itself into several categories: disagreement-based, regulatory arbitrage-based, tax arbitrage-based, and heuristic-exploiting. Quantifying each of these involves identifying individuals likely to be interested in purchasing the product and projecting the quantity of their anticipated demand. The methods most effective for this differ across the types of speculative activity, as we now discuss.

a. Pure disagreement-based gambling.-This is perhaps the hardest of all the forms of gambling to project demand on because so much depends on what catches the imagination of potential participants. Luckily, a large historical track record of past products offers a rich data set on which regressions using ex ante characteristics of products can be run to project ex post gambling. Such gambling can then be measured based on observed volumes compared to the demand accounted for by the other sources of demand (both insurance and other speculative forms discussed below). For example, one natural predictor of speculative demand is to survey professional forecasters for their estimates of the value of the security. ${ }^{48}$ If, for example, the forecasters agree on the value of the security, then it cannot be used to gamble. If the distribution of estimates is sufficiently wide, however, it can be used to gamble. Other predictive factors may relate to how prominent the phenomenon that the derivative is based on is in the public mind or in commonly used financial models. These can be quantified using new tools of automated text analysis, such as Google's Ngram Viewer. ${ }^{49}$ By harnessing data on past products and the speculative demand they generated, indicators like this could be used to form clearer expectations of likely speculative demand, in conjunction with documents that the proposer will submit about the sources of demand they anticipate and projections by similar but disinterested market players.

\footnotetext{
48 This view has been suggested by Simsek, supra note 9 , at 22 .

49 GOOGLE BOOKS NGRAM VIEWER, http://books.google.com/ngrams (last visited May 21, 2013).
} 
b. Regulatory arbitrage-based gambling.-Shen, Yan, and Zhang argue that financial instruments often give an opportunity to engage in gambling while posting less collateral or capital than would have been required for similar exposure in the past. ${ }^{50}$ More generally, new instruments offer opportunities for undermining capital requirements, including those being introduced in Basel III. ${ }^{51}$ The capital adequacy rules are supposed to prevent banks from taking excessive risk by requiring them to keep shareholder equity on the line, but financial innovation can result in products that enable banks to increase their exposure to risk without affecting their balance sheet. The potential demand for such innovation is particularly easy to gauge if data is available on the portfolios of the relevant institutions prior to the introduction of the innovation. These are disclosed in capital adequacy reporting and could be analyzed to determine how much exploiting new instruments would allow a bank to reduce its capital burden while maintaining the same exposure. This would then be used to quantify the regulatory arbitrage-based speculative demand, given estimates of the cost of holding capital widely available in the finance literature. ${ }^{52}$ Similar analyses would be possible for other regulations that might be arbitraged by new products, such as portfolio composition and separation between banking and investment banking activities.

c. Tax arbitrage-based gambling.-Tax arbitrage is a wellunderstood and measurable phenomenon. Firms hire tax lawyers to design products that enable investors to obtain lower tax rates without changing their real economic activity. The demand for tax arbitrage can thus be measured and used to estimate the arbitrage costs of the proposed instrument in the same manner as regulatory arbitrage..$^{53}$

d. Heuristic arbitrage-based gambling.-Heuristic arbitrage is more complicated. A large literature establishes that people's trading strategies often reflect simple heuristics (buy a stock that has recently increased in price) that can be easily exploited by hedge funds. ${ }^{54}$ By considering such heuristics and how they interact with the product's characteristics, the agency could project demand based on heuristic

\footnotetext{
$50 \mathrm{Ji}$ Shen et al., Collateral-Motivated Financial Innovation (Aug. 8, 2012) (unpublished manuscript), available at $\mathrm{http}: / / \mathrm{ssm}$.com/abstract=2014928.

51 Basel COMM. ON BANKING SUPERVISION, Basel III: A Global REgUlatory Framework FOR MORE RESILIENT BANKS AND BANKING SYSTEMS (rev. ed. 2011), available at http://www.bis.org/ publ/bcbs189.pdf.

52 David VanHoose, Theories of Bank Behavior Under Capital Regulation, 31 J. BANKING \& FIN. 3680,3695 (2007); Shen et al., supra note 50, at 3.

${ }^{53}$ For a general discussion of tax arbitrage involving derivatives, see David M. Schizer, Sticks and Snakes: Derivatives and Curtailing Aggressive Tax Planning, 73 S. CAL. L. REV. 1339 (2000).

54 See, e.g., De Bondt \& Thaler, Does the Stock Market Overreact?, supra note 30; Robert J. Shiller, Human Behavior and the Efficiency of the Financial System (Nat'l Bureau of Econ. Research, Working Paper No. 6375, 1998), available at http:/www.nber.org/papers/w6375.pdf.
} 
arbitrage. While doing so will be difficult in some cases, in others it will be relatively straightforward. For example, many investors and mutual funds heavily favor products with strong credit ratings even though these do not necessarily have better systemic risk than other lower rated products. While a rating is a proxy for systemic risk in some cases, it is a highly imperfect one. New products designed to achieve a strong rating, but with atypical systemic risk characteristics historically relative to other products carrying this high rating, are likely to generate a large demand from the institutions that focus on purchasing highly rated credit. ${ }^{55}$ This demand can be estimated based on previous demand for innovative, highly rated but systemically exposed derivatives.

Regardless of the difficulties of judging these questions, the agency's goal would not be to confidently project all potential consequences of introducing the new product into the distant future. Instead, it would reach a pragmatic expectation of likely short- to medium-term speculative and insurance demand for the products, just as the firm introducing the product would have to in order to project its likely profits. If these analyses, in their most general or one of their simplified forms, were to yield a clear answer on the balance of expectations, the inquiry could stop there. But if there is ambiguity, regulators can ask additional questions that require more judgment to answer. We turn to these now.

2. The Role that the Financial Product Plays in the Allocation of Capital.-A financial instrument may lower the cost of capital to firms and individuals. Such reductions in the cost of capital result from the ability to spread the risk more evenly. For example, prior to the securitization of "junk bonds" in the 1980s, many small firms could draw only on very wealthy investors for financing. Similarly, prior to the creation of mutual funds, as we discuss below, equity financing was available to a much more limited number of companies because venture capitalists were unable to sell their equity stakes in public markets. However, such benefits of new financial products are fundamentally just examples of one of the benefits of insurance. The current concentrated owners of the risky assets of the firm are able to sell them to investors better able to bear this risk because of their greater diversification. Thus, this classic "capital allocation" role of new financial instruments is subsumed in our first test, correctly interpreted. However, in the analysis of market demand, a special emphasis might in some cases be placed on the role a new structure would play in the financing of new firms, liquidation of existing inefficient firms, and the transfer of assets across firms.

\footnotetext{
55 See Donald MacKenzie, The Credit Crisis as a Problem in the Sociology of Knowledge, 116 AM. J. SoC. 1778 (2011) (arguing that such gaming of the system played an important role in creating the poor allocation of risk that destabilized the financial system and resulted in the credit crisis).
} 
Alternatively, a financial instrument could help create superior incentives for firms and managers within the firms, as some argued was the case with leveraged buyout structures and stock options. ${ }^{56}$ The value of such a structure in promoting beneficial incentives could be evaluated quantitatively using the standard techniques of theoretical and empirical contract theory. ${ }^{57}$

Benefits indirectly facilitated by improving the informational efficiency of prices would be more difficult to gauge. No research in finance theory has, to our knowledge, yet established any clear link between the informational efficiency of prices and the quality of real capital allocation. Thus, a high threshold would have to be met for claims by the promoter of the new product to persuade the agency of substantial benefits from improvements in informational efficiency. The improvement of informational efficiency alone would not be sufficient; a clear and cognizable link to the quality of capital allocation would have to be made.

3. How the Instrument Affects the Speed of Transactions.-If the creation of a new derivative facilitates high-frequency, informational racing transactions, this is an important cost that must be weighed against the instrument's benefits. For example, CDSs facilitate taking positions on the credit spread of a particular bond. This was possible, but difficult, before the invention of that instrument. To understand this point, suppose that an investor believes that GM bonds are likely to default and hopes to make money by betting on default. Before the invention of CDSs, the investor would adopt a short position on the bond by convincing someone to lend the bond to her in return for a promise to pay interest. The investor would then sell the bond at the current price, and when the debt became due, buy it again at the now lower (according to the buyer's expectation) market price, and return it to the lender plus interest. If the price fell enough, the investor made a profit by betting against GM. But this transaction was difficult to undertake. The investor would have to provide collateral to the lender to secure repayment, and the collateral or margin requirements would be quite high. By contrast, today an investor can bet against GM simply by buying a CDS on the GM bond, which pays out if GM defaults (and whose price increases as the risk of default rises). The margin requirements for exposure to CDSs are less costly than those for shorting.

${ }^{56}$ See Michael C. Jensen, Agency Costs of Free Cash Flow, Corporate Finance, and Takeovers, 76 AM. ECON. REV. 323, 325-26 (1986).

${ }^{57}$ On the theoretical side, see Bengt Holmström \& Jean Tirole, Market Liquidity and Performance Monitoring, 101 J. POL. ECON. 678 (1993), and Darrell Duffie, Innovations in Credit Risk Transfer: Implications for Financial Stability (Bank for Int'l Settlements, Working Paper No. 255, 2008) (providing a framework for evaluating the incentive benefits of Collateralized Debt Obligations (CDOs)). On the empirical side, see Emmanuel Saez, Using Elasticities to Derive Optimal Income Tax Rates, 68 REV. ECON. STUD. 205 (2001) (providing analysis of optimal income taxation using empirical data and a contract theoretic model). 
The cost savings can easily be measured by these avoided hassles, which could be gauged by asking financial consultants to structure the lowest cost means of gaining a desired exposure with and without the new instrument.

The difference is an implicit tax on the relevant transaction that is removed by the new instrument. The effect of removing such a tax is, of course, the opposite of introducing a tax, as suggested by James Tobin, as a means of slowing down the speed of financial transactions. ${ }^{58}$ Because it is easier to buy a CDS than to short a bond, the invention of CDSs increased the velocity and magnitude of trade based on bets as to whether a firm (or country) will default. It would be difficult to calculate the precise harm caused by this development, but it seems likely that most transactions deterred by a small transaction cost like the cost involved in shorting are unlikely to be of significant value because investors likely profit only from economically unimportant short-term asset movements. Thus, one can estimate the number of harmful transactions roughly by the effect of any past price movement on the cost of the transaction. Such movement allows the estimation of how much the volume of trading responds to its cost. Assuming all transactions that only occur when possible at sufficiently low cost are wasteful, one can combine this "elasticity" with the expected reduction in cost created by the new instrument to estimate the number of harmful transactions likely to be created.

4. Positive Externalities.-As we noted above, we are skeptical that most innovative financial instruments produce positive informational externalities. Nonetheless, the FPA should give the applicant the opportunity to prove that the positive externalities will exceed the cost. Proving that additional information is revealed is not sufficient: it must also be shown that this information is useful to individuals in the economy in their planning and in government decisionmaking.

For example, prediction markets, where people bet on public events like the winner of the next election, arguably create positive externalities because they greatly improve existing substitutes like polling. ${ }^{59}$ But these markets also allow people to gamble. It is unclear to us whether the benefits exceed the costs. Perhaps a strong case could be made for certain prediction markets, like those related to politics or international affairs. But other prediction markets, like those related to the lives of celebrities, seem unlikely to play a large enough role in economic planning to compensate for the harmful gambling they allow. ${ }^{60}$ This is likely the reason such markets remain illegal in the United States and are instead based abroad.

\footnotetext{
58 See James Tobin, A Proposal for International Monetary Reform, 4 E. ECON. J. 153 (1978).

59 See ABRAMOWICZ, supra note 41, at 9-11 (comparing prediction markets and polls for presidential elections).

60 The most famous prediction market was probably Intrade before it was shut down. See INTRADE, http:/www.intrade.com (last visited May 21, 2013).
} 


\section{Examples}

In this section, we use examples of actual derivatives to illustrate how our proposed FPA would evaluate applications for approval of new financial products. However, under our proposal all existing derivatives would be grandfathered; thus, we do not actually argue that a new FPA should evaluate these derivatives. The purpose of this discussion is therefore illustrative only.

1. Life Insurance.-We begin with life insurance because this financial product will be familiar to all readers and because it played an important role in the development of insurance regulation and, more broadly, financial products regulation. A breadwinner cares about the wellbeing of her spouse and knows that if she dies, her spouse's income will fall considerably. The breadwinner could save a portion of income in anticipation of this event, but a cheaper approach is to buy life insurance, which pays the spouse if and only if the breadwinner dies. Life insurance increases the individual welfare of the insured ${ }^{61}$ and the beneficiary by equalizing the beneficiaries' wealth over differing states of the world. A person is better off with the same income regardless of whether his spouse lives or dies than with a high income if his spouse lives and a low income if his spouse dies.

However, life insurance can also be abused to speculative ends. In eighteenth-century England, people would buy life insurance on politicians and other celebrities so that if the named person died, the purchaser of the insurance would receive a payout. ${ }^{62}$ While in principle, people could in this way insure against risks - for example, the risk of an economic crisis and loss of one's income if a statesman is assassinated-in practice people used life insurance products to gamble. Gambling is a socially wasteful activity because it increases the variance of one's income rather than (as in the case of insurance) reducing it. The law responded by developing the insurable interest doctrine, which prohibited insurance policies written on people in whom the buyer of the policy did not have a direct financial or emotional interest. $^{63}$

To understand how our proposal works, imagine that someone invents life insurance and seeks approval from the FPA. The agency must first ascertain the likely demand for life insurance for insurance purposes. First, the agency would estimate the number of people in the jurisdiction who are both breadwinners and have dependents, including spouses, children, and elderly parents. These people can potentially benefit from the introduction of life insurance through its insurance properties. The agency could go

\footnotetext{
61 Assuming that the insured is altruistic, which is normally the motivation for purchasing life insurance as the buyer cannot directly enjoy the payout.

62 CLARK, supra note 8, at 53.

${ }^{63} \mathrm{Id}$.
} 
further and estimate the actual aggregate value of life insurance by determining how much these people are on average willing to pay for life insurance given their next best option for insuring beneficiaries, which is through savings. Life insurance is superior to bank deposits for protecting dependents because life insurance frees up wealth for other consumption or investment purposes. Thus, the benefit of life insurance is that it enables breadwinners to provide protection to dependents at less cost than the nextbest mechanism of saving. A financial analyst can estimate the difference in cost using standard algorithms and then roughly estimate the aggregate social benefit by multiplying the number of breadwinners and the cost savings per breadwinner. Any other possible benefits from life insurance would also need to be estimated.

Second, the agency must estimate the potential costs of life insurance. The main focus will be gambling. The worry is that people might use life insurance to gamble on the lives of others, including celebrities and politicians. This behavior does not reduce risk for dependents or anyone else; it simply increases the risk or variance faced by the purchasers of life insurance policies, as is always the case with gambling. ${ }^{64}$ Potentially, the speculative cost could be very high. It is likely to be very difficult to estimate how much speculative activity will take place. If so, the agency could approve life insurance on a provisional basis and revisit its judgment at a later date. At this point, the agency would determine how much gambling takes place by demanding this information from life insurance companies using its subpoena power. The agency could then ban life insurance if (crudely) the number of speculative contracts exceeded the number of insurance contracts or (better, but more difficult) the aggregate loss of utility caused by the speculative contracts exceeded the aggregate gain in utility caused by the insurance contracts.

Fortunately, there is (and was) a better way to regulate. The agency could (and should) permit life insurance policies where an "insurable interest" exists and forbid them where such an interest does not exist. An insurable interest exists when the event that gives rise to the insurance payout actually causes a utility loss. ${ }^{65}$ For example, beneficiaries have an insurable interest in the death of the breadwinner because they will lose a source of income. ${ }^{66}$ The insurable interest requirement ensures that the life insurance is being used to insure risk (the payout occurs just when a loss is incurred) and not to gamble (where the payout occurs even if no loss is incurred).

\footnotetext{
${ }^{64}$ We ignore traditional moral hazard concerns, namely, that life insurance policies of this type give insurance owners an incentive to murder the insured person.

${ }^{65}$ See KENNETh S. Abraham, INSURANCE LAW AND REgulation 83 (5th ed. 2010).

${ }^{66}$ The law also recognizes insurable interests when there is a relationship of affection between the person whose life is insured and the beneficiary. Id. at 84 . We suspect this is just a proxy for a financial interest.
} 
This approach could be extended to other derivatives. When the agency is confronted with a derivative where there is both a lot of possible gain and a lot of possible harm simultaneously and where (like with life insurance) it is easy for a court ex post to gauge whether there was or was not an insurable interest, the agency could approve the derivative subject to the insurable interest requirement.

The agency would also consider the other factors that we have identified. There is no reason to believe that life insurance can be used to allocate capital in any significant way or to speed up transactions. Nor will life insurance have significant positive informational externalities (although conceivably a liquid life insurance market on important politicians could produce valuable information). Accordingly, these factors would play no role in the decision to approve life insurance.

However, it turns out that life insurance can be used for tax arbitrage. Over the last several decades, a number of U.S. firms such as Wal-Mart bought life insurance on their employees in order to obtain tax advantages. ${ }^{67}$ Congress and the IRS have responded with various rules that have limited, but not eliminated, the opportunities for tax arbitrage. ${ }^{68}$ While it is highly unlikely that the tax arbitrage costs would justify a ban on life insurance, the problems caused by arbitrage are an important reminder that even clearly beneficial financial products create hidden social costs.

2. Mutual Funds. - The modern financial market replays at a higher level of complexity the basic tradeoffs seen in the eighteenth-century life insurance market. Some products can be used only for insurance and do not serve speculative purposes. For example, one of the most important financial innovations of the mid-twentieth century was the creation of mutual funds, particularly mutual funds that closely tracked market indices. Mutual funds are companies whose assets consist of portfolios of stocks or other securities and sell shares in themselves to the public. ${ }^{69}$

Mutual funds created two major social benefits. First, they made more capital available to firms and entrepreneurs. Before the advent of mutual funds, many ordinary people stayed out of the stock and bond markets because of the high costs of trading. In order to maintain a diversified portfolio, one must frequently sell various securities (those that have appreciated) and buy others (those whose value has declined). This is costly and requires a great deal of attention. When an investor buys a share of a mutual fund, by contrast, she effectively delegates these tasks to a manager, who saves transaction costs because of economies of scale. When

\footnotetext{
${ }^{67}$ See Susan Lorde Martin, Corporate-Owned Life Insurance: Another Financial Scheme that Takes Advantage of Employees and Shareholders, 58 U. MIAMI L. REV. 653, 665-67 (2004).

68 Id. at 666.

69 See Anand G. Shetty, Mutual Funds, in 2 ENCYCLOPEDIA OF BUSINESS AND FINANCE 530-32 (2d ed. 2007).
} 
funds are designed to track an index of a group of assets, like the S\&P 500, the manager does little work and thus does not demand high compensation. With more people contributing to the stock and bond markets, the cost of capital for firms has declined. Mutual funds thus played a crucial role in shifting the funding model for start-up companies from bank financing to private equity financing with the possibility of exit to the stock market. Because traditional bank loans provided excessive incentives for risk taking ${ }^{70}$ mutual funds and the growth of equity markets that they sparked played a crucial role in the allocation of capital to entrepreneurs. ${ }^{\text {1 }}$

Second and closely related, mutual funds also generated an important but subtle insurance benefit. ${ }^{72}$ When investors buy shares of mutual funds, they are actually increasing their exposure to risk (at least, if they were using low-risk bank savings to buy the shares). But risk is reduced for the owners of firms, who no longer need to rely as much on their own assets to invest as capital markets expand. In aggregate, risk should decline simply because the relevant risk (that a firm's investment will go sour) is spread across more people-all the ordinary investors in the general public rather than just the firm's owners and a few other investors. This is a classic example of the insurance benefits of creating a more diversified and liquid financial market that we discussed above.

Meanwhile, mutual funds, especially index funds, brought little if any value to speculators or high-frequency traders. Shares were regulated so that they could only be purchased by individuals. Speculators and highfrequency traders typically deal in large volumes and gain little from the ability to buy a diversified portfolio at low transaction costs. ${ }^{73}$ Furthermore, as Gorton and Pennacchi argue, mutual funds were also specifically designed as investment vehicles for individuals and thus are unlikely to be useful for institutions or speculators. ${ }^{74}$ All these features were apparent at the birth of the mutual fund and much remarked upon even prior to such funds being widely available. ${ }^{75}$

Mutual funds-and again we have in mind index funds in particularalso create few opportunities for sophisticated investors to take advantage of heuristics. When ordinary people put their savings in index funds, they are not relying on any particular heuristics (like, buy a security whose value

\footnotetext{
70 The borrower enjoys the upside of the investment, while the downside is limited by bankruptcy; thus, the borrower has a strong incentive to gamble with funds obtained from bank loans.

71 Paul Gompers \& JOSh LeRNer, The Venture CAPITAL CyCle (2d ed. 2004).

72 In fact, in our framework, these two benefits are just two sides of the insurance coin, but we treat them separately for emphasis and clarity.

73 See William J. Baumol et al., The Economics of Mutual Fund Markets: Competition VERSUS REGULATION 126-28 (1990).

74 See Gary B. Gorton \& George G. Pennacchi, Security Baskets and Index-Linked Securities, 66 J. Bus. 1, 24 (1993).

${ }^{75}$ John C. Bogle, The Economic Role of the Investment Company 7-8 (Apr. 10, 1951) (unpublished A.B. thesis, Princeton University) (on file with the Northwestern University Law Review).
} 
has recently increased). In fact, financial theory teaches that optimal investment portfolios for individuals should be widely diversified and representative of the full set of possible investments, exactly what an index fund aims (and was designed) to achieve. ${ }^{76}$

3. Credit Default Swaps.-CDSs are derivatives in which the seller agrees to pay the buyer the value of an underlying bond if the issuer of that bond defaults. ${ }^{77}$ For example, a CDS on a Greek sovereign bond would pay its holder the value of the bond if the Greek government defaults on it. A CDS is covered if the holder also owns the underlying bond. A CDS is naked if the holder does not own the underlying bond.

A covered CDS cannot be used for gambling because its value is negatively correlated with the value of the bond. But by the same token, it is unattractive for investors. As Giglio points out, a CDS exposes the individual to counterparty risk when she can acquire insurance against the bond by selling it and purchasing a U.S. Treasury bond, which is zero risk. $^{78}$ As we explained earlier, CDSs are only useful as a way to avoid having to hold substantial offsetting short and long positions on Treasuries and the relevant bond to take speculative positions in these bonds. For this purpose, only naked CDSs can be used. Thus, CDSs serve almost exclusively as speculative devices or to promote high-frequency transactions.

Furthermore, as Giglio points out, CDSs generated significant "counterparty risk." When an investment bank sells CDS protection, the buyer is exposed to the risk that the bank will fail, in which case it will not be compensated if the underlying bond defaults. Because of the reduced cost associated with CDSs, arising from the lowered margin requirements, many clients were willing to accept this risk to engage in gambling. However, given that almost none of these clients were previously exposed to the risk of their counterparty prospering, this counterparty risk became a dangerous pitfall accompanying CDS positions.

Moreover, credit default swaps played little, if any, role in the fundamental allocation of capital, as was clear from their inception. Because they can only be used to take positions on bond or other credit issues already outstanding, they do not play a role (as with mortgage or junk bond bundling) in the placing of new bonds. On the other hand, as discussed above, they can significantly reduce the cost of trading large volumes of bets on existing credits, which have value primarily as a means

\footnotetext{
76 See Burton G. Malkiel, A Random Walk Down Wall STrEet (rev. ed. 2011).

77 See JOHN C. HULL, FUNDAMENTALS OF FUTURES AND OPTIONS MARKETS 565 (7th Global ed. 2011) (defining credit default swap).

78 Stefano Giglio, Credit Default Swap Spreads and Systemic Financial Risk 7-8 (Nov. 2012) (unpublished manuscript), available at https://sites.google.com/site/stefanogiglio/research (follow the article hyperlink).

${ }^{79}$ Id. at 7.
} 
of beating the market to judgments on the creditworthiness of a particular issue. Thus, CDSs facilitated informational racing but little capital allocation.

Some have argued that CDSs provided positive informational externalities by revealing the creditworthiness of borrowers. ${ }^{80}$ However, this argument is mistaken for two reasons. First, bond spreads over U.S. Treasuries or other safe issues were always readily available measures of creditworthiness, widely cited and used decades before CDSs entered the markets. ${ }^{81}$ Second, the performance of spreads as predictors of credit events has not obviously increased since the boom in CDSs. ${ }^{82}$ While Blanco, Brennan, and Marsh find that CDSs tend to incorporate new information about creditworthiness faster than do bond spreads, this may result simply from substituting activity away from the bond market to the CDS market. ${ }^{83}$ In fact, Bai, Philippon, and Savov find more broadly that financial innovation and the growth of the financial sector appear not to have increased the quality of information about security and credit values. ${ }^{84}$

In fact, a CDS is a highly imperfect measure of creditworthiness because its spread over the more basic risk-bond or safe-bond spread represents not different information, but rather the probability of the counterparty (that is, the party that issues the CDS) becoming distressed and thus defaulting. ${ }^{85}$ Giglio argues that there may be some positive informational externalities in clarifying the probability of such catastrophic meltdowns of counterparties and the financial system. ${ }^{86}$ This argument is persuasive because the CDS market could have (though appears not to have) offered a telling sign to regulators about the market's opinion about the probability of systemic financial failure. The benefits of such informational externalities would have to be judged against the other costs of CDSs and would almost certainly not make up for them, given the alternative sources of information about systemic risk, such as standard bond spreads on financial institutions. ${ }^{87}$

${ }^{80}$ Bloink, supra note 10 , at 631 (arguing that CDSs have positive information externalities in that they reveal the creditworthiness of debtors).

${ }^{81}$ Jennie Bai, Thomas Philippon \& Alexi Savov, Have Financial Markets Become More Informative? (Mar. 2012) (unpublished manuscript), available at http://papers.ssm.com/abstract= 2023889 (examining bond spreads going back to the 1970s). Spreads are simply the difference between the yield on the bonds and the yield on the Treasuries.

${ }^{82} \mathrm{Id}$. at 30.

${ }^{83}$ See Roberto Blanco et al., An Empirical Analysis of the Dynamic Relation Between InvestmentGrade Bonds and Credit-Default Swaps, 60 J. FiN. 2255 (2005).

${ }^{84}$ See Bai, Philippon \& Savov, supra note 81.

${ }^{85}$ Giglio, supra note 78.

${ }^{86}$ Id.

${ }^{87}$ For media criticisms of CDSs, see, for example, Floyd Norris, Naked Truth on Default Swaps, N.Y. TIMES, May 21, 2010, at Bl. For academic criticisms, see, for example, Kristin N. Johnson, 
If we imagined the CDS as being proposed for the first time by a financial innovator, we would expect the FPA to treat it skeptically. A complete ban on CDSs may be unwarranted because at least covered CDSs cannot be used for speculative purposes (although their insurance benefits are minimal as well). A reasonable approach would have been not to ban all CDSs, but to ban only naked CDSs-in effect, applying the insurable interest rule to this product.

4. Currency and Interest-Rate Swaps.-Currency and interest-rate swaps are agreements between two parties for one to pay to the other the net between the payments accruing on two different interest-bearing products or groups of products. ${ }^{88}$ For example, parties might swap bonds of similar maturities in two different currencies or swap a fixed-rate bond for a series of short-term bonds starting at different dates that together span the same maturity as the fixed-rate bond. In a common transaction between banks, a party swaps interest payments due to it based on a floating rate for interest payments due to another party based on a fixed rate, where the two interest streams have the same expected value. This is a way for the first party to reduce its exposure to risk and the second party to increase its exposure to risk.

Interest-rate and currency swaps are very similar to their close cousin, the CDS. While both may in principle be used for insurance, an investor can accomplish such insurance just as easily by selling one of the underlying fixed-income assets or currencies (the short side of the swap) and purchasing the other (the long side). Thus, most swaps are "naked" and intended to avoid the transaction costs of short selling to gamble on the relevant products. These swaps are used primarily for speculating on currencies or interest rates, both as pure bets and to evade various forms of regulation, including currency controls and capital requirements differing across different maturities of fixed income securities. Thus, traditional swaps, like CDSs, tend to engender significant gambling with limited insurance value.

While such gambling may help bring asset prices closer to their true values, thereby encouraging correct borrowing and savings decisions, again like CDSs, currency and interest-rate swaps do not allow entirely new trades to occur. Instead, they increase the ease and accelerate the pace of such transactions by reducing the necessity of short selling. Thus, such swaps primarily encourage informational racing and high-frequency trading rather than play an important role in the allocation of real capital.

Thus, the FPA, facing the introduction of swaps prospectively, would likely have prohibited them in the same way it would have prohibited

Things Fall Apart: Regulating the Credit Default Swap Commons, 82 U. CoLo. L. REV. 167, 202-06 (2011) (describing the costs of CDSs).

88 See AMIR SADR, INTEREST RATE SWAPS AND THEIR DERIVATIVES 25 (2009). 
CDSs. However, as with CDSs but with even greater history behind them, swaps would be grandfathered because much of the harmful regulatory arbitrage they permit is no longer possible because currency and capital controls have adjusted to prohibit the use of swaps for their most abusive purposes.

5. Equity Options.-Perhaps the canonical example of a derivative security, and one of those with the longest history, is the equity option. A call (put) option entitles the owner to purchase (sell) a stock at a given strike price. Options date back thousands of years and in most forms have obviously desirable economic properties. For example, the seller of a house might give the buyer an option to purchase the house at a certain price; this allows the buyer to invest in information about the house and neighborhood without worrying that the house will be sold to someone else. Equity options have a more recent vintage, and equity options exchanges go back only to the 1970s, when the Chicago Board of Trade created the first options exchange ${ }^{89}$ While it may appear that equity options are an effective way to insure risk associated with a stock, this is deceptive. One can always insure the risk on a stock simply by selling the stock and investing the proceeds in a (nearly) risk-free asset, such as Treasury bills.

Thus, the true exposure that options allow to be insured or gambled on is more subtle and was not well understood until the pioneering work of Black and Scholes and of Merton. ${ }^{90}$ Clearly, if an option is "in the money" already (if it is already profitable to exercise the option), it has some value simply mechanically. However, Black, Scholes, and Merton argued that the option has an additional value determined by the uncertainty over the movements of the underlying asset. This "option value" is related by a somewhat complex mathematical equation to the time remaining on the option and the uncertainty about its movements, but crucially, if the degree of uncertainty (or volatility) of the movements of the underlying asset is known, then the option value can be calculated mathematically. Thus, the only risk an option could insure, or bet the option would allow taking, is related to the volatility of the underlying asset rather than its actual value.

Except for risks created by options themselves, individuals and firms rarely, if ever, face risk related to the level of volatility of an asset rather than the value of the asset itself. Thus, options do not appear to play a significant insurance role. Instead, options are a classic example of a primarily speculative instrument. Options have been used to undertake a variety of types of harmful arbitrage: of heuristics, taxes, and capital regulations. Many firms during the 1990s used stock options as a form of

\footnotetext{
${ }^{89}$ See Brian Overby, The History of Options, in OPTIONS: EsSENTIAL CONCEPTS AND TRADING STRATEGIES I (Options Inst. ed., 3d ed. 1999).

${ }^{90}$ Fischer Black \& Myron Scholes, The Pricing of Options and Corporate Liabilities, $81 \mathrm{~J}$. POL. ECON. 637 (1973); Robert C. Merton, An Intertemporal Capital Asset Pricing Model, 41 ECONOMETRICA 867 (1973).
} 
compensation for executives because their value was less clearly known and thus it was possible to raise pay in a less transparent fashion. ${ }^{91}$ Because options can be used to gain or insure an exposure to a stock's value without purchasing or selling it, options have been extensively used to arbitrage tax regulations distinguishing the treatment of capital and interest income. ${ }^{92}$ Until capital adequacy regulations were adjusted to properly account for the risk exposure created by options in the transition from Basel I to Basel II, options offered an attractive way for firms to take positions in the market without committing the capital that would usually be requisite. ${ }^{93}$

Thus, options offer a perfect example of a harmful existing innovation. However, they also offer a clear case of why new innovations may be more dangerous than existing products that may have been harmful when they were themselves new. Options are now used much less frequently to reward executives (compared to standard stock grants) because it is well understood that they are used to game the system. ${ }^{94}$ Tax regulations have successfully closed loopholes created by the treatment of options. ${ }^{95}$ And capital adequacy regulations have similarly eliminated advantages to using options. Even pure disagreement-based gambling has declined as clearer mathematical models of option pricing have led to more precise estimates of option values on which different market participants used to disagree significantly. ${ }^{96}$

Thus, while the FPA would likely have prohibited options prospectively, the fact that it would not now ban them ex post is not likely to undermine efficient market functioning too severely. In fact, at this point, the positive informational externalities of being able to determine market volatility (information often used by policymakers at the Federal Reserve) may outweigh the remaining harms created by gambling on options. As a result, we believe that the highest priority is to avoid the future creation of more derivatives, to which the market has not yet adjusted and which will therefore fuel harmful gambling, rather than to restrict the use of existing products.

6. Statistical Derivatives.-A class of financial products sometimes referred to as statistical derivatives are based on properties of the distribution of asset returns, such as their volatility and correlation (across different assets), related to those that determine option value. Volatility derivatives pay off based on the average daily volatility of a stock or index

\footnotetext{
${ }^{91}$ Lucian Arye Bebchuk \& Jesse M. Fried, Executive Compensation as an Agency Problem, J. ECON. PERSP., Summer 2003, at 71, 82; Kevin J. Murphy, Explaining Executive Compensation: Managerial Power Versus the Perceived Cost of Stock Options, 69 U. CHI. L. REV. 847, 859-60 (2002).

92 See Schizer, supra note 53, at 1391-92.

93 See Partnoy, supra note 26, at 232.

94 Bebchuk \& Fried, supra note 91, at 82-83.

95 Schizer, supra note 53.

96 This is our perception; we cannot provide a citation.
} 
over a period, as measured by the variance of daily stock movements. Correlation swaps pay off based on various measures of correlation between the movements of stocks in a cluster (usually an index) over a period. For example, a common correlation derivative is based on the average pairwise correlation in daily stock movements over a period, such as a month. The derivative pays off if the stock values are correlated. ${ }^{97}$

Most popular are instruments that allow the taking of positions on the correlation structure of debt defaults, Collateralized Debt Obligations (CDOs), including the infamous CDOs of Asset-Backed Securities. ${ }^{98} \mathrm{~A}$ $\mathrm{CDO}$ is a financial instrument constructed from underlying bonds. The income streams from these bonds are combined and securitized according to various tranches or categories (e.g., mezzanine, equity, and debt), where investors who hold bonds based on the higher tranches are paid before investors who hold bonds based on the lower tranches. When the value of the underlying bonds are relatively uncorrelated, the risk to owners of the higher tranches is very limited - they receive nothing only if all or nearly all of the underlying bonds default because if only a few bonds default, the loss is absorbed by owners of the lower tranches. However, if all of the underlying bonds default at the same time, that is, if they are highly correlated, then the high tranches may be wiped out, even though they received limited compensation for this risk. Thus, by taking offsetting positions in different tranches, investors are able to gain exposure to or against the correlation between these debt defaults, which was not possible previously, when assets were simply packaged together and sold as a whole.

These instruments appear to play a few roles in the markets. First, many hedge funds extensively model the statistical properties of assets in order to price options and other preexisting derivatives and thus believe they have expertise on these. ${ }^{99}$ They use bets on these exotic derivatives to take positions directly in these properties, either for insurance or speculative purposes. Second, investment banks have created structured products that imbed these properties and sell them to consumers. ${ }^{100}$ It seems to be easy to market such positions to consumers because they appear to remove various components of risk that Taleb shows investors tend to overweight in some cases (the risk of small fluctuations of individual stocks) and underweight in others (the risk of systemic disaster). ${ }^{101}$ Third,

\footnotetext{
97 For a discussion of these and related derivatives, see, for example, SADR, supra note 88.

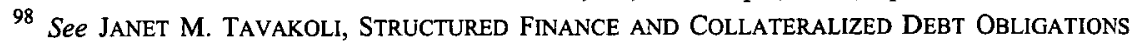
(2d ed. 2008).

99 See Peter Carr \& Roger Lee, Volatility Derivatives, 1 ANN. REV. FIN. ECON. 319 (2009).

100 See Anne-Sofie Reng Rasmussen, Index-Linked Bonds, MONETARY REV., 2d Quarter 2007, at 51,51 .

101 Nassim Nicholas Taleb, The Black SwaN: The IMPaCt of the Highly Improbable (2007).
} 
investment banks and hedge funds create products that satisfy various rules used to determine credit ratings for assets in ways that do not require actually reducing the relevant-to-investor risks. This led to large amounts of AAA-rated paper being churned out of CDOs despite this paper being highly systemically risky. ${ }^{102}$ That is, these derivatives are extremely useful for regulatory and evaluator arbitrage. Finally, sophisticated financial institutions use these products to engage in tax arbitrage in a similar manner. ${ }^{103}$

On the other hand, it appears that no financial institution or individual was, prior to the introduction of these derivatives, exposed to significant risk associated with the statistical properties, except those acquired through gambling on options. They also play little role in the allocation of capital because no investment decisions are based on the volatility of existing asset pricing and at best contribute to a limited extent to the informational efficiency of asset price levels that spur capital allocation because they are not directly related to the value of particular firm or sectoral investments. However, they have the potential to produce some positive informational externalities because volatility and correlation may have some predictive power regarding the direction of macroeconomic aggregates that may affect firm or policymaker decisionmaking.

In sum, given the numerous and clearly identifiable harmful uses and the tightly limited upside, it seems clear that a well-run agency would have rejected the introduction of such derivatives had they been proposed for approval.

7. Derivatives Based on National Income.-Shiller proposed the introduction of a small number (one or two) of derivative securities based on a weighted average (possibly negatively in some countries) of the GDP growth of the fifty-four countries in the Penn World Table Mark 5.5. ${ }^{104}$ That is, the derivatives were to pay out when the GDP of some countries rose and to lose value when the GDP of others fell. He argued that such derivatives would offer useful insurance to individuals living in many countries because the income individuals earn at work and their chance of retaining their jobs depends crucially on the state of their respective national economies.

To estimate the potential gains from insurance of introducing these securities, Athanasoulis and Shiller calculated the extent to which the riskiness of countries' income would be reduced as a result of the introduction of these securities based on more than forty years of GDP

102 For a critical discussion of how these securities came to be AAA rated, see Roger Lowenstein, Triple-A Failure, N.Y. TIMES MAG., Apr. 27, 2008, at 36.

103 Schizer, supra note 53, at 1341-42.

104 ROBERT J. SHILler, MACro MARKETS: CREATING INSTITUTIONS FOR MANAGING SOCIETY'S LARGEST ECONOMIC RISKS (1993). 
data. ${ }^{105}$ Using a standard economic model of optimal risk-return trade-offs, and assuming that everyone in a given country is identical, they calculated that Americans could gain roughly $\$ 400$ per capita by the reduction in the uncertainty about their income from insurance. ${ }^{106}$

However, Simsek notes that individuals with different beliefs could also use these derivatives to gamble on national income prospects. ${ }^{107}$ To calibrate this effect, Simsek considers a survey of professional forecasters by the Philadelphia Federal Reserve Bank. He assumes that the variance of beliefs about GDP among these forecasters is similar to that between individuals participating in the markets. These beliefs, in fact, widely differ across individuals. ${ }^{108}$ He thus calculates that if individuals engage in their optimal portfolio selection, given their beliefs, risk dramatically expands and the negative consequences of gambling swamp any gains from insurance and lead to thousands of dollars of lost welfare per capita. ${ }^{109}$ In fact, even if views among the public were an order of magnitude less dispersed than those among the forecasters, gambling would still outweigh insurance benefits. ${ }^{110}$ Thus Simsek's simple pass at the analysis we propose would lead to clear rejection of these derivatives. Furthermore, and revealingly, Simsek shows that given this spread of beliefs, the most profitable securities would not be the ones Athanasoulis and Shiller propose but rather others that would facilitate even greater gambling and would fail our test more severely. ${ }^{111}$

Of course, this analysis is extremely primitive and could be improved along a number of dimensions. An agency should use micro-level data to account for the possibility that different individuals in a given country are differently exposed to national income risk. It might also consider the interactions of the derivatives with taxes, regulations, and investor heuristics to consider arbitrage-inspired gambling. Surveys of investors rather than forecasters would be ideal. However, the Simsek analysis shows clearly how a very simple calculation based on coarse, publicly available data and textbook economic models can make a strong prima facie case against a new financial product, which then could be potentially rebutted or, if not, could form the basis of a case for prohibition or tight restrictions on marketing.

However, national income-based derivatives seem likely to bring significant benefits and little harm outside of the realm of the core insurance-gambling trade-off. In terms of the allocation of capital, national

\footnotetext{
105 Athanasoulis \& Shiller, supra note 9, at 1031-32.

106 Id. at 1046 \& tbl.2.

107 Simsek, supra note 9, at 37-38.

108 Id. at 3-4.

109 Id. at $31-32$

110 Id. at 3-4.

111 Id. at 38.
} 
income derivatives have the potential to begin the process of opening equity markets for the funding of national governments. Ultimately, countries may be able to sell shares of their future tax revenue (or closely related, their GDP) as equity. The sale of these shares may offer safer and more stable means of government finance than sovereign debt does, though derivatives based on national tax revenues rather than incomes may be more directly useful for this purpose. Derivatives based on national income also seem to have some of the clearest potential to yield valuable information to policymakers and businesses, given the importance of aggregate national income for a variety of planning. While national income derivatives could become a base for informational racing, they offer an entirely new arena for finance rather than simply allow acceleration of existing asset trades. Thus they do not seem clearly designed to accelerate the speed of trading even if they may have some potential side effects in this direction.

The bottom line is that national income derivatives would be a close run case for the agency, with strong arguments on each side. As is usual for such close cases, one cannot have great confidence that the agency would decide correctly, but the costs of an incorrect decision would also likely be low on net. Presumably as the agency gains experience, develops more detailed models, and draws on growing research stimulated by its operation, its ability to clearly adjudicate close calls would improve.

8. Real Estate Derivatives.-Another proposed derivative turns on the performance of the real estate market. Case, Shiller, and Weiss proposed the creation of securities based on the value of indices of real estate prices in different regions of the country. ${ }^{112}$ They reasoned that such derivatives would offer substantial opportunities for insurance, on both sides of the market, not currently available. Home owners and mortgagegranting banks cannot offload the risk associated with each individual house price directly by selling the house or mortgage on it to other individuals because this undermines incentives for taking care of the home ${ }^{113}$ or screening loan applicants. ${ }^{114}$ Thus, insurance is feasible only if indices of local home prices, over which individuals or firms have no direct control, can be used for insurance rather than the price of the individual home. However, McDuff shows that even quite coarse, regional indices explain a large part of the variation in prices of individual houses, and thus

\footnotetext{
112 Karl E. Case, Jr. et al., Index-Based Futures and Options Markets in Real Estate, J. PORTFOLIO MGMT., Winter 1993, at 83; Karl E. Case et al., Mortgage Default Risk and Real Estate Prices: The Use of Index-Based Futures and Options in Real Estate (Nat'1 Bureau of Econ. Research, Working Paper No. 5078, 1995).

113 See Edward L. Glaeser \& Jesse M. Shapiro, The Benefits of the Home Mortgage Interest Deduction 24 (Harvard Inst. of Econ. Research, Discussion Paper No. 1979, 2002).

114 Benjamin J. Keys et al., Did Securitization Lead to Lax Screening? Evidence from Subprime Loans, 125 Q.J. ECON. 307, 353-56 (2010).
} 
securities based on regional home price indices can provide significant insurance opportunities for home and mortgage owners. ${ }^{15} \mathrm{On}$ the other side of the market, many current renters face risk associated with house prices rising, thus pricing them out of the market for the future. Thus, real estate derivatives seem to offer substantial potential for social benefits.

They work like this. The derivative is linked to an index composed of a random sample of house prices from a region in which a person lives over a period. If house prices rise, the owner of the derivative sells the derivative and realizes capital gains; if house prices fall, a person who has shorted the derivative can liquidate her position and also obtain profits. In theory, a homeowner would want to be short on the derivative on her regional index and go long on derivatives for other regions where she might move. Thus, if the price of her house falls, she receives a payoff that offsets the losses she has presumably taken on her own house, and if it rises, she takes a loss presumably offsetting the rise in the value of her home. If housing in the region she may move to rises in price, she receives a payoff that partly compensates for the higher prices she is likely to have to pay for housing in the future; if it falls, she takes a loss partly offsetting the fall in housing costs she will face in the future. A renter would just do the long part. This would create a liquid market in these assets, and the payments would not be made bilaterally but rather based on how the index moved, plus whatever premium was necessary to make the market clear between the two sides.

On the other hand, it is possible that such indices could become vehicles for gambling. No obvious tax, heuristic, or regulatory arbitrage opportunities present themselves, but disagreements about the value of real estate were rampant, especially during the real estate bubble of the 2000 s, ${ }^{116}$ and thus, it seems possible that securities intended as insurance could end up instead being used by individuals with a view on the direction of the market, which could well increase their risk. For example, a homeowner bullish on the housing market seems just as likely to use the market to increase as to hedge her exposure to house prices. On the other hand, large preexisting vehicles for speculating on real estate nationwide already exist in the form of securitized mortgage debt and real estate equity funds. Thus, the primary additional area for gambling opened by these derivatives is that area related to particular regional markets. It thus seems likely that while real estate derivatives could in principle stimulate gambling, overall their net benefits on the insurance versus gambling dimension are positive.

Furthermore, were real estate derivatives to become widespread, they might have an important effect on the real allocation of capital. Costs of insuring home prices, were such index-based insurance to become the norm, could help check purchaser expectations about continually rising

115 DeForest McDuff, Home Price Risk, Local Market Shocks, and Index Hedging, 45 J. REAL EST. FIN. \& ECON. 212, 213 (2012).

116 ROBERT J. SHILlER, IRRATIONAL EXUBERANCE (2d ed. 2005). 
home prices and thus make a bubble less likely in an asset class that is notoriously difficult to sell short. Given the illiquid nature of housing derivatives, at least initially, it seems unlikely that they would fuel a market sufficiently vigorous to be the source of a large amount of informational racing. Finally, the externalities created by the existence of projections of regional house prices could be substantial because real estate bubbles are an important concern of fiscal, monetary, and regulatory policymakers. Thus, it seems very likely that the FPA would have approved real estate derivatives.

In fact, these derivatives were created as the S\&P Case-Shiller Index Housing Derivatives and listed on the Chicago Mercantile Exchange (now the Chicago Board of Trade) in 2006. ${ }^{117}$ As Shiller reports, the market largely flopped, generating only a total of $\$ 612$ million in total positions over the course of the following year and a half; the market has further declined in size since then. ${ }^{118}$ Thus, in reality, the Case-Shiller derivatives appear to have ended up having neither the benefits nor the costs that could have been projected ahead of time. This is an example of why important factors determining the impact of derivatives (the quality of marketing, infrastructure, etc.) can affect their eventual impact in ways that are difficult to predict. Nonetheless, Shiller reports information on who purchased contracts that indicates that its impact, while small, appears to have been net positive. Thus, while the projections on both the positive and negative size of this derivative would have been overblown, it seems that the direction of the decision would likely have been correct.

9. Commodities Futures Markets.-Futures contracts allow two parties to agree to exchange a commodity at a future date according to standardized terms. Futures contracts have their history in and most common application to commodity markets, particularly agriculture and energy. They are one of the oldest forms of insurance. Although there were predecessors in other countries, the modern futures market in the United States was developed in Chicago in the mid-nineteenth century to address agricultural commodities like pork bellies. ${ }^{119}$ In a futures contract, the seller agrees to deliver a certain quantity of a certain standardized commodity at a certain future date in return for a fixed payment. A farmer could therefore be assured of the price he or she would be paid at the time of planting and

117 S\&P DOW JONES INDICIES, S\&P/CASE-SHILLER HOME PRICE INDICES: ECONOMIC INDICATORS (2013), available at http://us.spindices.com/documents/factsheets/fs-sp-case-shiller-home-price-indicesltr.pdf; S\&P/Case-Shiller Home Price Index Futures, CME GrouP, http://www.cmegroup. $\mathrm{com} /$ trading/real-estate/residential/SandP-case-shiller-home-price-index.html (last visited May 21, 2013).

118 John Y. Campbell et al., Understanding Inflation-Indexed Bond Markets, BROOKINGS PAPERS ON ECON. ACTIVITY, Spring 2009, at 79.

119 See Dennis W. Carlton, Futures Markets: Their Purpose, Their History, Their Growth, Their Successes and Failures, 4 J. FUTURES MARKETS 237, 245 (1984). 
so could avoid over- or underplanting, while a wholesaler could be assured of the price it would pay at the time of delivery and so could avoid over- or underinvesting in transportation, storage, and so forth. In this way, the seller insures against a price decline, the buyer insures against a price rise, and total risk exposure is reduced.

Futures also can be a means for gambling. Futures exchanges, like the famous Chicago Mercantile Exchange, have long hosted large numbers of speculators not directly involved in either consumption or production who participate in these markets. ${ }^{120}$ However, a large fraction even of these speculators are involved in the market in some physical capacity. Many take advantage of the fact that many of the commodities can be stored. If the intertemporal pattern of prices reflected in the market diverges from the costs of storage net of interest, these speculators store the commodity (or run down stores) to keep prices in line. While such behavior may seem speculative, it affects the real allocation of economic resources and therefore is socially beneficial.

In fact, Adam Smith wrote in The Wealth of Nations:

By making [the great body of the people] feel the inconveniencies of a dearth somewhat earlier than they otherwise might do, [a futures speculator] prevents their feeling them afterwards so severely as they certainly would do, if the cheapness of price encouraged them to consume faster than suited the real scarcity of the season. When the scarcity is real, the best thing that can be done for the people is to divide the inconveniencies of it as equally as possible through all the different months, and weeks, and days of the year. The interest of the corn merchant makes him study to do this as exactly as he can . . . ${ }^{121}$

Thus, futures markets play a crucial role in the allocation of real economic resources, analogous to the allocation of capital motive we highlight. They also influence commodity producers' planning and investment decisions, having additional follow-on effects on the allocation of real resources.

Futures markets are deliberately designed to increase the speed and ease with which expected future prices can be incorporated into the operation of markets and thus clearly accelerate the speed of trade. However, unlike in other markets such as purely financial markets, this additional speed may actually be warranted by the impacts it has on economic activity. While companies' financing decisions are taken relatively infrequently and thus feedback from price signals over short time ranges is not very important, decisions about commodities investment, storage, and consumption are made by large numbers of individuals. This means that at any moment in time, some individual is likely to be making a relevant decision affecting the real economy. Thus, up-to-date price signals

\footnotetext{
120 See Hazen, supra note 18 , at 990.

1212 ADAM SMITH, AN INQUiRY INTO THE NATURE AND CAUSES OF THE WEALTH OF NATIONS 35 (Edwin Cannan ed., Methuen \& Co. 5th ed. 1930) (1776).
} 
are much more valuable in commodities futures markets than in other markets. Additionally, the information created by these prices typically has important beneficial spillovers as well because many governments intervene in commodities markets and need projections of the future of these markets to plan effectively.

Thus, it seems clear that whatever the harms from gambling in commodities futures markets, an FPA would be very likely to approve them were the issue to come up anew.

\section{Relationship with the Insurable Interest Rule and the Law Against Wagering}

1. The Insurable Interest Rule.-As noted in the discussion of life insurance, a useful strategy for regulation is to approve financial products on the basis of the insurable interest requirement: the owner or beneficiary of the product receives a financial payout if and only if she incurs a loss of some sort. The payout could be explicitly contingent on the loss, as in the case of a conventional life insurance policy or a covered CDS. Or it could be merely correlated with the loss. The insurable interest rule is a powerful method for restricting gambling while permitting insurance.

It should therefore not be surprising that the insurable interest rule has been in existence for more than two hundred years. ${ }^{122}$ However, it has had less influence on U.S. financial markets than it should have had for two reasons. First, there has been a great deal of uncertainty about the scope of the insurable interest requirement. Second, there has been some controversy over the policy basis of the insurable interest requirement.

The scope problem arises because virtually all financial transactions transfer risk, and yet no one wants to believe that all financial transactions are insurance policies. At the very least, such a view would cause regulatory havoc. It implies that state insurance agencies would have jurisdiction over virtually all financial products-when it is generally understood that there needs to be a division of labor between the state insurance agencies and federal securities agencies like the SEC and the CFTC, and that state insurance agencies have no expertise over financial products other than conventional insurance policies. To avoid regulatory overlap, state insurance agencies have limited their jurisdiction to conventional insurance policies issued by traditional insurance companies and avoided defining financial derivatives as "insurance." Famously, the New York insurance agency refused to regulate CDSs in $2000 .^{123}$

But the regulatory division of labor and the insurable interest rule should not be confused. Even if we want state insurance agencies to

122 See Life Assurance Act, 1774, 14 Geo. 3, c. 48 (Gr. Brit.).

123 Re: Credit Insurance Policy Issued to Financial Institution, State of N.Y. Ins. Dep't Informal Opinion (June 16, 2000), available at http://www.dfs.ny.gov/insurance/ogco2000/rg006161.htm. 
regulate only conventional insurance companies that serve consumers and businesses, it does not follow that the insurable interest rule should not be applied to financial products. What follows is just that some other agency, such as our proposed FPA, should apply the rule to financial products.

The policy controversy concerns whether the basis of the insurable interest is moral hazard, gambling, or something else. The traditional policy basis was a combination of moral hazard concerns and gambling. The moral hazard argument is that if a person can buy insurance on the life of a person or the existence of an object in which she has no financial interest, then she will have an incentive to kill that person or destroy the object (for example, burn down a building on which she owns insurance). The moral hazard argument is problematic. ${ }^{124}$ Insurance companies bear some of the cost of moral hazard, so they have strong incentives to deter it - for example, simply by refusing to issue insurance when there is no insurable interest or imposing deductibles or other restrictions. Recently, related concerns have arisen over the CDS market. Some commentators believe that holders of naked CDSs on Greek bonds have an incentive to block efforts to rescue Greece because they receive their payoff if the Greek bonds default. ${ }^{125}$ To the extent that CDSs end up in the hands of politically influential entities, they could cause serious harm to negotiations. However, this fear appears to be speculative at the current time.

The gambling argument has always played a subordinate role in policy debates. ${ }^{126}$ The reason is probably that economists presume that sophisticated parties should be free to enter any transactions that they want to enter unless the transactions produce externalities, and gambling does not (unless it increases systemic risk). Other concerns - for example, that it is immoral to bet on another person's life or property-seem antiquated.

However, as we have shown, the gambling problem is real and can be given a solid founding in economic theory. Products that increase risk exposure should be presumptively illegal. Thus, a revival of the insurable interest requirement would improve social welfare.

124 For a number of practical criticisms that seem to tum on problems in enforcement, see Jacob Loshin, Note, Insurance Law's Hapless Busybody: A Case Against the Insurable Interest Requirement, 117 YALE L.J. 474 (2007). Loshin's main point seems to be that the doctrine will cause insurers to issue excessive insurance because the doctrine excuses them from payout. However, by the same token, the doctrine should make insurance without an insurable interest exceedingly unattractive for buyers, thus reducing the demand for insurance without an insurable interest.

125 See, e.g., Nelson D. Schwartz \& Eric Dash, Banks Bet Greece Defaults on Debt They Helped Hide, N.Y. TIMES, Feb. 25, 2010, at A1 (late edition); Abigail Moses, Greece Credit-Default Swaps May Pay Out if Losses Exceed 21\%, BLOOMBERG BUSINESSWEEK (Oct. 12, 2011), http://www.business week.com/news/2011-10-12/greece-credit-default-swaps-may-pay-out-if-losses-exceed-21-.html.

126 See, e.g., David Mengle, The Economic Role of Speculation, ISDA RES. NOTES, Issue 2, 2010 , available at http://www.isda.org/researchnotes/pdf/SpeculationRN.pdf. But see Stout, supra note 13; our view is similar to hers. 
2. The Rule Against Wagering.-A related rule is the common law restriction on wagering contracts. All states have statutes that ban or heavily regulate gambling, and the courts have inferred a general public policy against gambling or wager contracts. ${ }^{127}$ However, even as they were developing this rule, courts quickly discovered that distinguishing a wager from a legitimate contract is difficult to do. One early thought that was quickly dismissed was that any contract that involved risk was a wager contract. ${ }^{128}$ For example, a contract that paid off if the coin came out heads would be invalid because the probability of heads is less than one. However, virtually all contracts involve risk of this type; certainly, all legitimate insurance contracts do, as does any sale of goods where, for example, there is a nonzero probability that the goods will be destroyed in transit or contain some defect.

Courts quickly realized that an identical contract could be used for gambling or legitimate insurance purposes. The standard example is the farmer who plants today and then expects to harvest a good crop if the weather is good and a bad crop if the weather is bad. To protect himself against the risk, the farmer enters a forward or futures contract where the price of the crop is guaranteed. The price of the contract will reflect the risk; the buyer agrees to a relatively high price minus a discount that reflects the risk of the bad outcome. This contract serves as insurance because it reduces the variance in payoffs for the farmer. Meanwhile, the buyer could protect itself from risk by entering contracts with farmers in multiple locations unlikely to experience the same weather.

Yet the exact same contract could be used for betting. Suppose that the probability of the good outcome is one-half and the probability of the bad outcome is one-half. Two gamblers could enter a futures contract to gamble on the outcome. What makes their contract a gamble rather than insurance is that the contract exposes them to more risk rather than less-and the reason for this is that the payoff is not correlated with the bad outcome, as it is for the farmer (who receives a payoff if and only if his crop is destroyed). The crucial point to understand is that a court cannot distinguish an insurance contract from a gambling contract merely by inspecting the contract's terms; it must also know the portfolios of the parties and the relationship between the risk embodied in the contract and the risk exposure in the portfolios.

Courts did not appear to understand this problem. Instead, they kept inventing vaporous doctrinal formulations to help them distinguish gambling and insurance transactions. For example, a contract would be deemed a gambling contract if the parties intended to gamble, acted in bad

\footnotetext{
127 See, e.g., McDaniel v. Tullis, Craig \& Co., 11 S.W.2d 203, 205 (Tex. Civ. App. 1928).

128 See Roy Kreitner, Speculations of Contract, or How Contract Law Stopped Working and Learned to Love Risk, 100 COLUM. L. REV. 1096, 1100-03 (2000).
} 
faith, or did not have a legitimate interest. ${ }^{129}$ None of these gambits worked because, as Kreitner notes, a legitimate contract and a gambling contract are formally or analytically indistinguishable. ${ }^{130}$ Kreitner seems to argue that there really was no difference between insurance and gambling contracts and that the courts simply expressed the public's ambivalence toward capitalism (our "love/hate relationship with risk"131). Many other authors seem to take the same view. ${ }^{132}$ But as we argued in Part I.A, there is a crisp analytic difference between a transaction that increases the parties' aggregate risk exposure and a transaction that does not increase the parties' aggregate risk exposure. The courts seem to have grasped the basic distinction between increasing risk and reducing risk but did not realize that to apply this distinction to the cases, they could not limit themselves to an evaluation of the contract but had to examine the financial holdings of the parties as well. ${ }^{133}$ Perhaps some courts did realize this but believed that such a standard would be unworkable. Or perhaps they believed that the newly created regulatory agencies of the New Deal could handle the problem more effectively. In any event, as the twentieth century progressed, courts gradually stopped holding that financial transactions violated the public policy against gambling.

3. Ex Post Versus Ex Ante Regulation.-The insurable interest rule and the ban on wagering contracts are ex post rules. Parties can enter any contract they want, but when one party breaches and the other party seeks to enforce the contract in a court, the court will then apply the rule and either void the contract or supply the victim with another remedy. We advocate instead an ex ante system, where financial innovators must obtain the approval of an agency before selling new products. In some cases, the agency will simply do a cost-benefit analysis and ban a product if the speculative costs exceed the insurance benefits. In other cases, the agency might determine that the product should be permitted subject to conditions - for example, that it be sold only to those with an insurable interest. We provide more details in Part II, but what is important to understand is that the underlying theory for the insurable interest rule, the ban on wagering contracts, and our proposed form of ex ante regulation is the same. The difference lies in the institutionalization or legal application of the theory.

129 See id. at $1126-27$

130 Id.

131 See id. at 1096-1101.

132 See, e.g., Hazen, supra note 18; Pat O’Malley, Moral Uncertainties: Contract Law and Distinctions Between Speculation, Gambling, and Insurance, in RISK AND MORALITY 231 (Richard V. Ericson \& Aaron Doyle eds., 2003).

${ }^{133}$ See Irwin v. Williar, 110 U.S. 499, 506 (1884) (allowing the jury to base its decision solely on the nature and circumstances of all of the parties' transactions). 


\section{AN FDA FOR THE FINANCIAL MARKET}

\section{A. Structure of the Financial Products Agency}

We now turn to the question of how our approach could be institutionalized. We propose a regulatory agency, the FPA, which would be the FDA of financial derivatives. The inventor of a financial product will not be able to sell it to the public without first submitting an application to the FPA and receiving approval. The FPA will evaluate the product using the test that we described above. The agency will approve, reject, or approve the project subject to certain conditions. For example, as noted, the agency might in close cases permit the inventor to sell the product only where the product serves an insurable interest of the buyer. If the inventor sells the product to buyers without insurable interests, then the contract will be unenforceable in court. Such a course would be particularly attractive not only when cases were close, but especially when determination of whether an insurable interest exists ex post is particularly feasible, as with life insurance or swap contracts as discussed above. The inventor and others will then be able to market an approved product subject to the conditions, if any. Anyone who markets a product without regulatory approval will be subject to legal sanctions, and the contract that embodies the product will not be enforceable in court.

Numerous legal and institutional issues would need to be addressed, including how independent the agency should be, whether the agency should have the power to issue binding rules, whether it should contain adjudicatory mechanisms, the extent of judicial review, and so forth. These are standard questions of administrative law that we will leave for others or for future work because of their complexity. ${ }^{134}$

There are two useful analogies for the FPA. The first is review of new pharmaceuticals by the Food and Drug Administration. Manufacturers must submit applications to the FDA and obtain approval before marketing new drugs. ${ }^{135}$ The major portion of the review process involves expensive and time-consuming randomized clinical studies. This approach provides a model for the review of financial innovations; however, the analysis of proposed financial products should be much cheaper and quicker because it will rely on existing publicly available data and will involve relatively mechanical number crunching in most instances.

Particularly along this dimension (the cost, length, and nature of the approval analytics process), the FPA would be more similar to a second precedent: the review of proposed mergers by the Department of Justice and the Federal Trade Commission. When two firms seek to merge, they

${ }^{134}$ For useful discussion of some of these issues, see Omarova, supra note 5, at 131-35.

135 Federal Food, Drug, and Cosmetic Act, Pub. L. No. 75-717, § 505, 52 Stat. 1040, 1052-53 (1938) (codified as amended at 21 U.S.C $\$ 355$ (2006)). 
must give notice to one of these agencies. ${ }^{136}$ The relevant agency then evaluates the proposed merger using a test embodied in the Horizontal Merger Guidelines. ${ }^{137}$ The test requires the agency to balance any anticompetitive effects resulting from the increase in market power of the merged entity against any efficiency benefits resulting from economies of scale or other synergies. Like in our approach to financial innovation, applicants must obtain ex ante approval from government agencies by satisfying a test that combines quantitative and qualitative factors. The main difference is that a merger is a one-shot contract; unlike a financial innovation, it does not involve the creation of intellectual property. Also, the primary justification for regulating new financial products is the direct harm they cause to their consumers, as with medicine, rather than the externalities they cause, as with mergers.

\section{B. Parallels Between Pharmaceutical and Financial Products Regulation}

Commentators have criticized the FDA process ${ }^{138}$ and the mergerapproval process, ${ }^{139}$ but there has been little effort to abolish them, suggesting that the consensus is that these screening mechanisms are socially desirable even if they can be improved along the margins. Nonetheless, it is clear that they are exceptional. Most other products and commercial decisions in American society are not under such rigorous control: while the government may occasionally inspect for safety, test properties of products, and allow lawsuits if harms occur, pre-approval of new products is uncommon outside of medicine. The question thus arises why financial innovation is more like pharmaceutical innovation than like other products of the U.S. economy. There are a number of answers.

1. Subjective Preferences and Expertise.-The best medicine for an individual to take is not something highly idiosyncratic to that individual, conditional on her observable symptoms. While different individuals usually respond differently to different treatments, this reaction is usually as unpredictable to the individual as it is to the doctor treating her or to anyone else prior to the treatment being administered. Thus the key consideration in determining the appropriate medicine is usually the use of the medical community's expertise to determine the objectively best treatment for the patient rather than the treatment that she subjectively

${ }^{136}$ Hart-Scott-Rodino Antitrust Improvements Act of 1976, Pub. L. No. 94-435, $\S 201,90$ Stat. 1383,1390 (codified as amended at 15 U.S.C. $\$ 18 \mathrm{a}(2006)$ ).

137 U.S. DEP'T OF JUSTICE \& FED. TRADE COMM'N, HoRIzONTAL MERGER GuIdelines (2010), available at $\mathrm{http} / / \mathrm{www}$.justice.gov/atr/public/guidelines/hmg-2010.html.

138 See, e.g., RICHARD A. EPSTEIN, OVERDOSE: How EXCESSIVE GOVERNMENT REGULATION STIFLES PHARMACEUTICAL INNOVATION (2006).

139 See, e.g., Joseph Farrell \& Carl Shapiro, Horizontal Mergers: An Equilibrium Analysis, 80 AM. ECON. REV. 107 (1990); Gina M. Killian, Note, Bank Mergers and the Department of Justice's Horizontal Merger Guidelines: A Critique and Proposal, 69 NOTRE DAME L. REV. 857 (1994). 
prefers. Not only do individuals usually consult doctors about the best medicine; doctors usually base their opinions on centrally conducted research.

These features of the market for medicine contrast sharply with those of most consumer products. When shopping for TVs, computers, or books, individuals usually know far more about their tastes than any expert would be capable of learning in any reasonable period of time. This capability makes allowing individual choice and providing individuals with richly detailed information (rather than a blunt permission or prohibition) far more important in most product markets than in health. And it makes access to expert advice much more important in health than in other product markets.

Economic theory teaches us that finance is much like medicine. Individuals' optimal investment portfolios differ between individuals relatively little, except in ways that can be readily observed and described based on a small number of individual characteristics. These characteristics include risk preferences, age, the industry in which one is employed, and where one lives. ${ }^{140}$ On the other hand, optimal financial planning is a complicated computational problem that is at the frontiers of both economic theory and computer science. ${ }^{141}$ The vast majority of the well-off seek advice about the allocation of their financial assets but rarely do so about other life decisions.

2. Delayed and Uncertain Feedback.-A classic mechanism that corrects poor decisionmaking in many settings and that actually allows individuals to learn far more about their settings than experts can is prompt and clear feedback about their success or failure. This has been demonstrated in a wide range of economic and psychological experiments. ${ }^{142}$ An important problem in medicine is that such feedback often comes with long delays and is often garbled by uncertain outcomes and placebo effects. Medicines that are inefficacious often do not show themselves to be so until the medication has been used for a long period, and efficacious medicines are often only effective on a small number of patients. Medicines can often have subtle but corrosive long-term side effects or may only have negative side effects with small probability. Therefore, whether on net the medicine is worth it is something that requires detailed scientific analysis, as is forced by the clinical trials required for FDA approval. Such settings are ideal for ex ante agency

140 JOHN Y. CAMPBELl \& LUIS M. Viceira, STRATEGIC ASSET Allocation 3-4 (2002).

${ }^{141}$ Id.

142 See, e.g., Ryan K. Jessup et al., Feedback Produces Divergence from Prospect Theory in Descriptive Choice, 19 PSYCH. SCl. 1015 (2008); Robert Wood \& Albert Bandura, Impact of Conceptions of Ability on Self-Regulatory Mechanisms and Complex Decision Making, $56 \mathrm{~J}$. PERSONALITY \& SOC. PSYCH. 407 (1989). 
regulation rather than tort remedies because victims do not learn of the harm until it is too late..$^{143}$

This delayed and uncertain feedback is actually far more prevalent in finance. While most medicines usually yield some results within a year or two, many financial instruments do not show their underlying frailty until a once-in-a-lifetime financial crisis hits. Many ex ante sensible investments turn sour and many ex ante ludicrous investments prosper, at least for some period. Thus individuals can persist in making poor investment decisions for very long periods without receiving clear feedback about this.

3. Extent of Potential Danger.-If you buy the wrong food, you may get sick, and if you buy the wrong cell phone, you may face a serious disruption to your work life. But the potency of medicines tends to mean that making the wrong decision has a very severe left tail that, while it may be relatively low probability, can be devastating in the case it occurs. This makes extensive testing to ensure such outcomes are avoided crucial in medicine. As Americans discovered during the recent financial crisis, financial markets can have severe negative effects not just for individuals but for whole societies. Thus the dangers of financial products seem at least as extreme as the dangers of medicines.

\section{Criticisms and Qualifications}

Our proposal is not a panacea. We acknowledge that any new form of regulation is not to be undertaken lightly. Agencies often make mistakes, interfere with markets, and slow down innovation, and they can be captured by interest groups. In this section, we anticipate and respond to some objections.

1. Delay and Bureaucratic Risk Aversion.-Critics of the FDA argue that it imposes unnecessary delays on the marketing of drugs, driven in part by bureaucratic risk aversion-FDA officials will be hauled before Congress if they wrongly approve a drug that causes death or severe side effects, but not if they excessively slow down approval even when the social costs of doing so are greater than the risks. ${ }^{144}$ As a result, the FDA relies too much on extremely rigorous clinical tests and not enough on other forms of research. We do not know whether this criticism is accurate, but even if it is, we believe that bureaucratic risk aversion poses less of a threat to financial innovation than it does to pharmaceutical innovation. There are two reasons for this. First, despite the terrible effects of dangerous financial products, their harms are not as vivid as birth defects or premature deaths, so the publicity value of grilling errant regulators will be lower. Second, we believe that the benefit of additional financial

\footnotetext{
143 STEVEn Shavell, Foundations of ECONOMIC ANALYSis OF LAW 398, 400 (2004).

144 See SuSAN Thaul, CONG. RESEARCH SERV., RL32797, Drug SafeTy aND EFFECTIVENESS: ISSUES AND ACTION OPTIONS AFTER FDA APPROVAL 1-2 (2005).
} 
innovation is less than the benefit of additional pharmaceutical innovation because it is already possible to use financial products to insure quite efficiently, and market participants are wary about adopting even beneficial financial products. Accordingly, even the most promising recent financial innovations, such as the Case-Shiller housing derivatives, have met with limited market demand, as discussed above. ${ }^{145}$ Thus, the cost of false negatives is lower.

2. Agency Capture.-Another theory of government or agency failure is the opposite: that far from being risk averse and eager to avoid public controversies, agency officials are eager to use regulation to benefit the regulated industry, a phenomenon known as agency capture. ${ }^{146}$ Many critics of financial regulation have used capture theory to explain why they oppose regulation; they fear that if regulators are given more power, they will use it to protect the financial industry from competition rather than protect investors from the financial industry. ${ }^{147}$ But although capture theorists can point to specific examples where regulators misused this authority in this way, as a general theory of regulation it is overdrawn. It would justify eliminating all government agencies (including, say, the military), and it is hard to reconcile with the obvious fact that most of the time, industry opposes rather than welcomes the creation of new regulatory bodies. Certainly, Dodd-Frank has not received much enthusiasm from the financial industry. ${ }^{148}$ Furthermore, because most new financial products open new markets rather than compete directly with existing products, it seems less likely that industry groups will try to exploit the agency to shut down competition. Such claims are rarely made about the FDA, for example, compared with other regulatory agencies in industries where entry of close competitors, rather than new products, is monitored.

3. Line-Drawing Problems and Issues of Generality.-Possibly the most difficult problem is defining a "financial product" for the purpose of review. ${ }^{149}$ Consider, for example, the CDS. Would the inventor of the first

145 IPD/IPF Trade Volume Report UK, IPD (Jan. 31, 2013), http://www.ipd.com/Portals/1/ Derivatives\%202013/Q4\%202012\%20Derivates\%20trading\%20volumes\%20UK.pdf.

146 See, e.g., George J. Stigler, The Theory of Economic Regulation, 2 BELL J. ECON. \& MGMT. SCI. 3 (1971).

147 See, e.g., Merton H. Miller, Do We Really Need More Regulation of Financial Derivatives? (U. Chi. Graduate Sch. of Bus., Selected Paper No. 75, 1994), available at http://www.chicagobooth.edu/ / media/254758677A0740A58EC34D1532EC5E0E.pdf.

${ }^{148}$ See, e.g., Ben Protess, United in Disdain for Dodd-Frank, Wall Street Is Split on the Details, N.Y. TiMES DEALBooK (Oct. 5, 2011, 7:47 PM), http://dealbook.nytimes.com/2011/10/05/wall-stunited-in-disdain-for-dodd-frank-but-split-on-the-details.

${ }^{149}$ See, e.g., Alireza M. Gharagozlou, Unregulable: Why Derivatives May Never Be Regulated, 4 BROOK. J. CORP. FN. \& COM. L. 269 (2010) (discussing line-drawing problems for regulation of derivatives generally); M. Todd Henderson, Credit Derivatives Are Not "Insurance," 16 CONN. INS. L.J. 1, 23-26 (2009) (opposing treatment of CDSs as insurance for regulatory purposes because of linedrawing problems). 
CDS have been required to obtain approval, or only the inventor of the first naked CDS, or the inventor of the first naked CDS to be used to insure against sovereign bonds, or just Greek bonds? Our tentative view is that the inventor of the initial CDS should be required to obtain agency approval. In the case of a financial product with many potential uses, the agency may determine that it will be approved only for certain uses (akin to the approval of new pharmaceuticals). The inventor or subsequent inventors may then seek approval for more specialized uses based on additional data or changes in market conditions.

A related problem could arise if investors choose to evade an FPA's restrictions on a particular financial product by customizing a one-shot transaction that is functionally identical or closely related to the banned product. This is, however, a generic problem in financial regulation, and not a new one. The FPA and courts would need to do an ex post functional analysis to determine whether the parties evaded the law through the manipulation of legal forms or had an independent and valid economic reason to enter into the transaction. Even if such adjudication is imperfect, preventing abusive products from being cheap and standardized would significantly raise the cost of using them and thus their prevalence.

One elegant solution to this problem would be to deprive the agency of the power to block financial products and instead give it the power only to license financial products. A financial innovator would be free to market a product without prior authorization, but state anti-wager and insurable interest laws would apply, and so subsequently a party could avoid enforcement of any contract where the financial product was used to gamble rather than to insure. To avoid the legal uncertainty, a financial innovator could apply to the FPA for a license or no-action letter that stated that the financial product satisfied our social welfare test and thus was lawful. A licensed financial product would be immune to challenge in court. Under this approach, people would (in theory) refuse to use financial products for gambling purposes because they could not enforce their payouts, while financial products mainly used for insurance purposes would be unaffected.

4. Failures of Expertise.-A frequent complaint is that agencies cannot attract the top talent and as a result are unable to understand and regulate the products under their jurisdiction. This criticism is overdrawn. Many agencies-including the FDA, the Justice Department, and the Fedhave attracted top talent and can also contract out for it by paying consultants. Furthermore, requiring pre-approval will provide firms seeking approval an incentive to hire experts to provide the market research necessary to establish the value of a product as happens extensively in both merger and new pharmaceutical review, thus reducing the evaluative burdens on the agency. The FPA would, of course, though, need to be 
designed like the FDA or the Fed so that its officials are adequately compensated.

5. The Regulation of Existing Products. - The statute that created the FDA grandfathered existing drugs; we would be tempted to do the same. It would be arguably too difficult for a financial products agency to review every financial instrument that exists. Critics might argue that we would therefore fail to regulate many of the financial products that contributed to the 2008 crisis, including our bete noire, the naked CDS. Nonetheless, new products are usually the most harmful: since market participants have had little opportunity to adapt to them, they create the greatest confusion and opportunity for regulatory arbitrage. Moreover, new products provide greater opportunities for gambling than old products do because new products are harder to value. As market participants learn about products, their valuations should converge; gambling takes place only when valuations differ. Finally, the expectation of profits from new products encourages people to overinvest in developing those products and attracts top talent from leading universities that might otherwise go into more socially valuable fields. ${ }^{150}$

That said, we acknowledge that many existing products may cause more harm than good, and so we would not rule out prohibitions on existing products. One possibility is to leave such regulation to Congress; another is to permit the agency to impose bans on existing projects but under a strict standard that requires the agency to make a clear showing that an existing project is socially harmful. Thus, while our focus is prospective, it does not preclude existing financial instruments from being regulated in some other way.

6. Elimination of Incentives to Innovate Because of Loss of Intellectual Property.-The invention of the CDS required a major intellectual and financial investment, as related by Tett. ${ }^{151}$ Investment banks invent these products because they expect to profit from them, and they profit by making them available to customers before competitors have developed similar products. Once the idea becomes public, competitors can duplicate it, driving down the price and profits. Investment banks may therefore not engage in financial innovation if they can expect their products to be stuck in review for a substantial period of time, during which the details become publicly available.

This concern is exaggerated. Investment banks probably already have excessive incentives to invest in new financial products, which, as we have seen, have only ambiguous net social benefits. In addition, original

${ }^{150}$ Ezra Klein, Harvard's Liberal-Arts Failure Is Wall Street's Gain: Ezra Klein, BLOOMBERG VIEW (Feb. 15, 2012, 7:00 PM), http://www.bloomberg.com/news/2012-02-16/harvard-liberal-artsfailure-is-wall-street-gain-commentary-by-ezra-klein.html.

151 See TETT, supra note 3, at 10-12. 
financial products are potentially patentable, although the doctrine at present is extremely murky. But if insufficient incentives turn out to be a problem, a possible solution is to grant investment banks limited intellectual property protection-for, say, one year-after their products have received approval.

7. Less Burdensome Alternative Forms of Regulation.-One might believe that less heavy-handed forms of regulation are possible, including disclosure and labeling requirements. ${ }^{152}$ Reformers have advocated the Tobin tax on financial transactions, which would reduce gambling by making it less profitable. ${ }^{153}$ The new Consumer Finance Protection Bureau is designed to protect consumers from shoddy financial practices. Traditional capital adequacy requirements prevent banks and other financial institutions from taking on excessive risk. The capital adequacy requirements, which have been a familiar part of the regulatory landscape in the United States for many decades, might seem sufficient for limiting gambling.

We do not reject alternative forms of regulation, but we do not believe that they are sufficient. Disclosure rules are notoriously weak; ${ }^{154}$ this approach is clearly inadequate for pharmaceutical regulation, where people, even with the help of their doctors, have trouble evaluating the effects of drugs. The Tobin tax is poorly targeted; it increases the cost of beneficial insurance as well as gambling. The CFPB addresses only a small slice of the overall problem. And traditional capital adequacy regulation, while necessary, has proven inadequate because it did not prevent the 2008 financial crisis. The problem with capital regulation is that banks and other financial institutions can game the rules precisely by using the kinds of derivatives that we would prohibit. Thus, capital adequacy regulation and financial products regulation are complements.

8. Substitution to Unregulated Activities.-If the agency has authority to regulate only new financial products, then investors who seek to gamble can simply gamble on older financial products, like CDSs, which will remain lawful under our proposal. And even if regulation reached all financial products, then investors who seek to gamble could switch to legal gambling in Las Vegas and Atlantic City. Thus, it may be doubted that implementation of our proposal would have a nontrivial effect on behavior. $^{155}$

152 See articles cited supra note 11.

153 Paul Krugman, Op-Ed., Taxing the Speculators, N.Y. TIMES, Nov. 27, 2009, at A39.

154 See, e.g., Omri Ben-Shahar \& Carl E. Schneider, The Failure of Mandated Disclosure, 159 U. PA. L. REV. 647 (2011).

${ }^{155}$ Cf. Henderson, supra note 149 , at 32 (making the substitution argument to oppose treatment of CDSs as insurance for regulatory purposes). 
Like the line-drawing problem, the substitution problem is a generic objection to any form of regulation because regulators must draw lines, and typically people can find near substitutes just on the other side of the line. This objection rarely prevails because in practice the regulatory arbitrage is more costly than engaging in the prohibited activity, so the regulation, at a minimum, serves as a tax on socially costly behavior.

9. People Should Be Permitted to Gamble if They Want.-In economic models, people are generally assumed to be risk averse. For such people, it is not rational to gamble. Why, then, is gambling so common?

We can imagine three reasons. First, many people are simply foolish: they believe that they can beat the odds by using tricks or relying on lucky numbers or totems. Such people eventually lose their money and are not made better off by gambling, whatever they might think. ${ }^{156}$ Second, some people become addicted to gambling in the classic sense that they report that they do not want to gamble but then gamble anyway, in the process disrupting relationships, losing their homes, and suffering other losses. Many people take steps to overcome their gambling addiction; in some states, gamblers can put their names on lists that are sent to casinos, which must then bar them from entering. ${ }^{157}$ Third, people might treat gambling as a form of entertainment, like going to a movie, in which one pays for a complex sensory experience that enhances one's utility.

If these observations are correct, then gambling should be illegal, as it is in many jurisdictions, or should be confined to settings in which it is maximally entertaining while creating the minimum risk. This is largely what our present system of limited and regulated casinos and lotteries accomplishes.

But even if one agrees that people should be allowed to gamble in casinos, it would be a serious error to conclude that they should be able to gamble by buying and selling securities. When people gamble on sophisticated financial instruments, they are simply misusing a device that they probably do not understand, that generates far greater risk than traditional gambling does, and that yields minimal entertainment value. ${ }^{158}$ Finally, we should note that most of the gambling that is engaged in by sophisticated institutions like investment banks is probably driven by regulatory arbitrage. This type of gambling is clearly socially harmful.

\footnotetext{
${ }^{156}$ For a recent analysis of the economics of gambling, see Nicholas Barberis, A Model of Casino Gambling, 58 MGMT. SCI. 35 (2012).

157 New Jersey, for example. See Press Release, N.J. Office of the Att'y Gen., Division of Gaming Enforcement Announces Increased Initiatives for Self-Exclusion During Problem Gambling Awareness Month in New Jersey (Mar. 5, 2013), available at http://nj.gov/oag/newsreleases13/pr20130305a.html.

${ }^{158}$ In his fair analysis of the economic cases in favor of and against gambling, Eadington emphasizes that one of the main defenses of gambling is its entertainment value and not simply the consent of those involved. William R. Eadington, The Economics of Casino Gambling, $13 \mathrm{~J}$. ECON. PERSP. 173, 186 (1999).
} 
10. Financial Activity Will Flee Abroad.-If certain financial products are banned in the United States, they will be marketed abroad, and American companies, including financial institutions, will be able to access them through international transactions. This is a potentially significant problem with our proposal, and so ultimately, the United States would need to coordinate its policies with those of other countries where major financial centers are located, like the U.K. However, this problem is not unique to our proposal; it is a generic problem for financial regulation of all types. For example, capital adequacy regulation is also subject to international evasion, and this has given rise to the various Basel agreements to set international capital adequacy standards. A similar process will probably be needed for our proposal as well, but this is best left for future research.

\section{CONCLUSION}

Any proposal to introduce new regulations will be controversial because of legitimate concerns that regulation interferes with the efficient allocation of resources and is vulnerable to capture by interest groups. In the current, highly polarized political environment, it is easy to predict that many people will regard our proposal as an excessively radical reform, one that is inconsistent with free market traditions in the United States. It is therefore important to emphasize that our proposal in large part revives an old regulatory system that served the United States well until it was overwhelmed by financial innovation in the 1990s and then dismantled. One of our main goals is to establish a more sophisticated version of the insurable interest rule and the common law restriction on wagering that will block gambling while permitting socially valuable insurance. Even our proposal for an FDA-like agency is not as radical as it sounds. Every state has an insurance agency that possesses the power to regulate financial instruments that have insurance-like components, as financial products frequently do. At the federal level, the CFTC and the SEC already have jurisdiction over financial products. For IPOs, the SEC must approve securities in advance of the public offering, although currently its review is limited to ensuring that disclosure requirements are satisfied. ${ }^{159}$ The CFTC has the power to block financial innovators from selling their products on exchanges. ${ }^{160}$ Our goal is simply to provide these and related agencies with the right powers and guidance so that they can regulate these products effectively.

159 See Larry W. Sonsini, Preparing the Registration Statement, in 2 SECURITIES LAW TECHNIQUE ch.19 (A.A. Sommer, Jr. ed., 2012).

160 The CFTC recently used this power to ban an entrepreneur from selling political events contracts. See Press Release, U.S. Commodity Futures Trading Comm'n, CFTC Issues Order Prohibiting North American Derivatives Exchange's Political Event Derivatives Contracts (Apr. 2, 2012), available at http://www.cftc.gov/PressRoom/PressReleases/pr6224-12. 
NORTHWESTERN UNIVERSITY LAW REVIEW 